\title{
TOWARD AN UNDERSTANDING OF THE ECONOMICS OF CHARITY: EVIDENCE FROM A FIELD EXPERIMENT**
}

\author{
Craig E. LandRY \\ ANDREAS LANGE \\ JoHN A. LIST \\ Michael K. PRice \\ NichOLAS G. RUPP
}

\begin{abstract}
This study develops theory and uses a door-to-door fund-raising field experiment to explore the economics of charity. We approached nearly 5000 households, randomly divided into four experimental treatments, to shed light on key issues on the demand side of charitable fund-raising. Empirical results are in line with our theory: in gross terms, the lotteries raised more money than the voluntary contributions treatments. Interestingly, in terms of both maximizing current contributions and inducing participation, we find that a one-standard deviation increase in female solicitor physical attractiveness is similar to that of the lottery incentive.
\end{abstract}

\section{INTRODUCTION}

In 2003 , more than $\$ 240$ billion-exceeding 2 percent of U. S. GDP - was contributed to American philanthropic organizations. Even though charitable giving continues to grow at rapid rates, relatively little is known about the economics of charity. Early fund-raising efforts typically relied on voluntary contributions mechanisms (VCM), but recently other methods have surfaced. For example, lotteries have helped to fund everything from Harvard, Princeton, and Yale Universities to local public goods such as bridges and municipal buildings. ${ }^{1}$ While lotteries continue to grow increasingly popular-lotteries have now spread to every state except Utah and Hawaii-their relative efficacy remains

* The Editor, Lawrence Katz, and two anonymous reviewers provided remarks that significantly improved the study. Thanks to Daniel Hamermesh, Glenn Harrison, Liesl Koch, John Morgan, David Reiley, Adrian Sargeant, seminar participants at Columbia University, the Massachusetts Institute of Technology, the Wharton School at the University of Pennsylvania, and the 2005 ASSA meetings for providing comments that improved the manuscript. Jamie BrownKruse worked with us in her capacity as the Director of the Hazards Center. Andreas Lange gratefully acknowledges funding by the Deutsche Forschungsgemeinschaft (DFG) under grant LA 1333/2-1.

1. Interestingly, the first lottery in America was held in 1612 in Jamestown with the proceeds providing half of the town's budgeted operating expenses. George Washington used a lottery to assist in the funding of the continental army and purchased the first ticket for a federal lottery-sponsored to finance improvements in Washington, D.C.-in 1793 [Rodgers and Stuart 1995].

$\odot 2006$ by the President and Fellows of Harvard College and the Massachusetts Institute of Technology.

The Quarterly Journal of Economics, May 2006 
underresearched. Indeed, even the most primitive facts concerning alternative fund-raising mechanisms are largely unknown.

Our study focuses on several key issues in the economics and practice of charitable fund-raising by providing a theoretical model as well as a door-to-door field experiment to test the theory. $^{2}$ Our theory models individual contribution decisions under the VCM, the VCM with an initial seed money donation, and both the single- and multiple-prize variants of a charitable lottery. The underlying framework includes an extension of Andreoni's [1989, 1990] impure altruism model, allowing solicitor/solicitee interaction to influence contribution levels. Our theory predicts that the total provision of the public good in the VCM treatment where seed money is provided exceeds that elicited from a VCM without seed money. Furthermore, every lottery we consider dominates the VCM in both total dollars raised and the number of contributors attracted. The intuition behind this result is that competition for a private lottery prize introduces a compensating externality that attenuates the free-rider problem [Morgan 2000]. This negative externality reduces the difference between private and social benefits from contributing to the public good and thereby increases total contributions to the public good relative to a situation where no lottery prize is provided.

We investigate the effects of using lotteries and seed money in an actual charitable giving campaign by taking advantage of a unique opportunity to organize a capital campaign at East Carolina University (ECU). We designed the campaign closely following fund-raiser guidance and our theoretical model by randomly dividing solicitors into four treatments: two that made use of the VCM and two that used lotteries.

Several interesting insights emerge. For example, the lottery treatments raised roughly 50 percent more in gross proceeds than our VCM treatments. This result is largely driven by greater participation rates in the lotteries: lotteries increase participation rates by roughly 100 percent. This finding highlights an attractive feature of lotteries: they provide fund-raisers with a tool to generate "warm lists," or a larger pool of active donors to draw from in future fund-raising drives. This result is important in light of the fact that fund-raising strategists typically rank

2. We would have preferred to test our theory using a much less laborintensive fund-raising method-such as a phone or mail solicitation-but regulatory guidelines concerning lotteries prohibit the use of these types of solicitations for such a gambling exercise. 
building a "donor development pyramid" as the most important aspect of a successful long-term fund-raising effort. ${ }^{3}$ In this spirit, use of lotteries provides the fund-raiser with a "double dividend," earning more funds immediately as well as securing a larger warm list than VCMs garner.

Our experimental design also permits an exploration of whether, and to what extent, individual solicitor characteristics influence fund-raising success. We find that a one-standard deviation increase in physical attractiveness among women solicitors increases the average gift by approximately 35 to 72 percent. This result is largely driven by increased participation rates among households where a male answered the door. While this finding might not be surprising to marketers ${ }^{4}$ such an "apples-to-apples" comparison between "mechanism" and "nonmechanism" treatment effects is rare in the literature. In this sense, our finding that the "physically attractive" treatment effect is in the neighborhood of the difference in fund-raising success between our theoretically most attractive approach (lotteries) and our least attractive approach (voluntary contributions) is of significant note. There is also some limited evidence that other solicitor characteristics, such as obesity and self-confidence, influence fund-raising success, and that social connectivity between the solicitor and household matters.

The remainder of our study proceeds as follows. The next section provides our theoretical framework on which we base our field experiment. Section III describes our field experimental design. Section IV summarizes our findings. Section V assesses alternative interpretations of the experimental findings. Section VI concludes.

\section{Theoretical Model}

We present a simple model of the voluntary provision of public goods to provide direction to our field experimental design and to highlight the factors that determine giving in a door-to-door fundraising campaign. Because the actual interaction between solicitors and solicitees might play an important role in the context of door-

3. This long-term aspect of building a donor base is invaluable because start-up fund-raisers typically lose money in their first few attempts (see, e.g., Sargeant, Jay, and Lee [2005]).

4. A number of studies have explored personal characteristics and the effectiveness of marketing. A recent study that performs this exercise in the economics literature is Bertrand, Karlan, Mullainathan, Shafir, and Zinman [2005]. 
to-door fund-raising, and potential contributors might experience a "warm-glow" from giving to specific solicitors, we apply a variant of Andreoni's [1989, 1990] impure altruism model.

We concentrate on an economy with $n$ symmetric agents who derive utility from consuming a numeraire good, $y_{i}$, a public good at level $G$, and (possibly) from their own contribution $b_{i}$ to the public good. Each agent faces a budget constraint $y_{i}+b_{i} \leq w$ and derives ex post utility according to

$$
U_{i}=u\left(y_{i}\right)+h(G)+\gamma f\left(b_{i}\right),
$$

where $u(\square), h(\square)$, and $f(\square)$ are (strictly) increasing and concave. ${ }^{5}$ The term $\gamma f(\square)$ depicts the warm-glow effect from giving, which depends on the solicitor and solicitee characteristics, as described by the parameter $\gamma$. Throughout, we assume that provision of the public good is socially desirable, $n h^{\prime}(0)>u^{\prime}(w)$.

Under the voluntary contribution mechanism (VCM) without seed money, individuals give according to the first-order condition (for an interior solution):

$$
u^{\prime}\left(w-b^{n S}\right)=h^{\prime}\left(n b^{n S}\right)+\gamma f^{\prime}\left(b^{n S}\right),
$$

where $b^{n S}$ denotes the individual contribution level. Concavity of the utility functions immediately implies that contributions under the VCM are increasing in $\gamma$.

If a charity can announce "seed money" contributions $\left(P_{0}\right)$ prior to eliciting contributions from the public at large, then it can gain credibility or reveal the type and value of the public good which may increase equilibrium contributions. ${ }^{6}$ Since seed money increases the existing provision level of the public good, however, marginal utility may be reduced leading to lower individual contributions. While individual contributions $\left(b^{S}\right)$ may be smaller or

5. Note that we allow for risk aversion with respect to the numeraire consumption good $\left(u^{\prime \prime}(\square) \leq 0\right)$. The additive separability allows us to concentrate on the impact of increased risk aversion with respect to the numeraire as measured by $-u^{\prime \prime}(\square) / u^{\prime}(\square)$. We do not make any specific assumption on the functional form of $u(\square)$; thus, properties such as constant/increasing/decreasing absolute or relative risk aversion are special cases of our analysis.

6. Andreoni [1998] discusses a different effect of seed money: his model of charitable giving for a threshold public good has multiple equilibria, and in the absence of seed money there exists a Nash equilibrium with zero charitable giving. The zero-contribution equilibrium can be eliminated, however, by initial commitments of seed money, which lower the remaining amount needed to be raised in the public fund-raising campaign. Thus, in his model seed money is used as an elimination device rather than as a credibility device. List and LuckingReiley [2002] provide a test of this effect of seed money and find evidence in favor of seed money acting as a credibility device, consonant with our theoretical model. The interested reader should also see Vesterlund [2003]. 
larger than those without seed money, total provision of the public good $\left(n b^{S}+P_{0}\right)$ will exceed that elicited from a VCM without seed money, $n b^{n S}$.

\section{II.A. Charitable Lotteries}

Consider a charitable fund-raiser that uses a (single prize) lottery in order to alleviate the strong free-riding incentives in the VCM. The probability $\pi_{i}^{L}$ of an agent winning the prize $P^{L}$ depends on all agents' contributions $b_{j}(j=1, \ldots, n) .{ }^{7}$ The expected utility of an agent $i$ is therefore given by

$$
E U_{i}^{L}=\pi_{i}^{L} u\left(w-b_{i}+P^{L}\right)+\left(1-\pi_{i}^{L}\right) u\left(w-b_{i}\right)+h(B)+\gamma f\left(b_{i}\right),
$$

where $B$ represents aggregate contributions to the public good. Maximizing (3) with respect to $b_{i}$ leads to the first-order condition for the optimal contribution level:

$$
\begin{array}{r}
0=\frac{\partial \pi_{i}^{L}}{\partial b_{i}}\left[u\left(w-b_{i}+P^{L}\right)-u\left(w-b_{i}\right)\right]-\pi_{i}^{L} u^{\prime}\left(w-b_{i}+P^{L}\right) \\
-\left(1-\pi_{i}^{L}\right) u^{\prime}\left(w-b_{i}\right)+h^{\prime}(B)+\gamma f^{\prime}\left(b_{i}\right) .
\end{array}
$$

This optimality condition directly implies that individual (and therefore aggregate) contributions to the public good are increasing in $\gamma$. Further, the chance of winning a lottery prize gives agents an additional incentive to contribute to the public good. As such, we can compare the equilibrium contributions with those under the VCM.

Proposition 1. With symmetric agents and any finite level of risk aversion, average individual contribution levels to the public good under a lottery exceed those under the VCM.

Proof. See Landry, Lange, List, Price, and Rupp [2005].

Importantly, this result depends on the assumption that the perceived value of the public good does not depend on the choice

7. If the agent purchases $b_{i}$ tickets and each opponent contributes $b_{-i}$, her probability of winning the prize is given by $\pi_{i}^{L}=b_{i} / B$, where $B=b_{i}+(n-1) b_{-i}$. We concentrate on symmetric equilibria; thus, the probabilities are given by $\pi_{i}^{L}=1 / n$ and for the partial derivative we obtain

$$
\frac{\partial \pi_{i}^{L}}{\partial b_{i}}=\frac{1}{n b} \frac{n-1}{n}=: \frac{1}{n b} H^{L} .
$$

For formal proofs of all results and a more formal treatment of lotteries that pay several prizes, see Landry, Lange, List, Price, and Rupp [2005]. 
of institution-VCM or lottery. If running lotteries affects the credibility of a charity, we cannot compare the rank ordering of contributions. Since we cannot control for this in our field experiment, our empirical results provide a conservative test on the dominance of the lottery as a fund-raising mechanism.

\section{II.B. Single- Versus Multiple-Prize Lottery}

Rather than providing a single prize, a fund-raiser could decide to split the prize budget into several smaller prizes. While this reduces the maximum amount an agent can win, it increases the chances of winning some prize lowering the variance in ex post wealth. Consequently, multiple-prize lotteries can increase average contributions if agents are risk-averse. Furthermore, multiple-prize lotteries can outperform single-prize lotteries if agents are heterogeneous with respect to their valuation of the public good.

\section{II.C. Effects on the Extensive Margin}

Thus far, our comparisons have focused on the symmetric cases, leading to mechanism gains arising on the intensive margin, i.e., participation rates are identical, but average contributions increase. This changes if we allow agents to have heterogeneous marginal valuations for the public good. With heterogeneous valuations for the public good, only those agents with the highest marginal valuations contribute under a VCM. Charitable lotteries, however, may induce participation by agents with lower marginal valuations because such contributions provide both private and public benefit. This highlights a potential "doubledividend" of using lotteries: not only are aggregate contributions enhanced, but the prize structure can induce greater participation rates.

\section{II.D. Individual Characteristics}

The role of individual personal attractiveness on market outcomes has been demonstrated by recent empirical studies (see, e.g., Hamermesh and Biddle [1994] and Biddle and Hamermesh [1998]). ${ }^{8}$ In addition, economists have recently begun to provide

8. There is also some evidence from laboratory experiments that such relational matters are important. For example, Andreoni and Petrie [2004a, 2004b] find experimental evidence that identifying participants in a public goods experiment by showing their pictures has a substantial influence on giving behavior. Mobius and Rosenblatt [2004], likewise, find beauty effects in their labor market 
theoretical models relating individual self-confidence (or related personality constructs) and market outcomes (see, e.g., Bénabou and Tirole [2002]). If a similar phenomenon occurs in our field environment, then differences in solicitors' attractiveness and confidence may affect the realization of our model parameter $\gamma$ and associated contributions. In designing our experiment, we carefully measure each of these factors.

\section{EXPerimental Design}

Following our theory, we designed a door-to-door fundraising solicitation to allow a clean comparison between four different treatments: a VCM with and without seed money, a fixed-prize lottery with only a single cash prize, and a fixed-prize lottery with multiple cash prizes. Door-to-door fund-raising is widely used by a diverse range of organizations. While there is a large literature on the benefits of interpersonal, door-to-door solicitations as opposed to less personal solicitation methods (see, e.g., Fraser, Hite, and Sauer [1988]), to our best knowledge these comparisons consider only VCMs.

\section{III.A. Part I: The Experimental Treatments}

In each treatment, households in predetermined neighborhood blocks in Pitt County, North Carolina, were approached by a paid solicitor and asked if they would like to make a contribution to support the Center for Natural Hazards Mitigation Research at East Carolina University. ${ }^{9}$ Households that answered the door were provided an informational brochure about the Hazards Center and read a fixed script that outlined the reason for the solicitors' visit. The script included a brief introduction that informed the resident of who the solicitors were, the purpose of their visit, a two-sentence summary of the nonprofit organiza-

experiments. Relatedly, evidence on the importance of social interaction on trust and cooperative behavior can be found in Glaeser, Laibson, Scheinkman, and Soutter [2000] and Dufwenberg and Muren [2002].

9. The Natural Hazards Mitigation Research Center was authorized to begin operations in the fall of 2004 by the North Carolina state government. The Hazards Center was founded in response to the widespread devastation in Eastern North Carolina caused by hurricanes Dennis and Floyd, and designed to provide support and coordination for research on natural hazard risks. For more information on the Hazard Mitigation Research Center, see http://www.ecu.edu/ hazards/. Our field experiment should therefore be considered a "natural" field experiment, in the parlance of Harrison and List [2004]. 
tion, and the details of the charitable raffle (when applicable). A copy of the script for the single-prize lottery is provided in Appendix 1.

Across all treatments, potential donors were informed that proceeds raised in the campaign would be used to fund the Hazards Center. In the VCM with seed money treatment, potential donors were also informed that the Hazards Center had already received a commitment of $\$ 1000$ from an anonymous donor. In the single-prize lottery treatment, households were informed that each dollar contributed to the Hazards Center would provide them with one ticket for a raffle where the winner would receive a $\$ 1000$ prepaid credit card. In the multiple-prize lottery treatment, households were informed that each dollar contributed would provide one chance in a raffle that would award four $\$ 250$ prepaid credit cards as prizes. Households were informed that they were eligible to win only one of the four prepaid credit cards. Agents in the lottery treatments were informed that their chances of winning the raffle would be based upon their ticket purchases relative to the number of tickets purchased by other households in Pitt County.

At this point, it is important to consider that we attempted to make the field experiment correspond closely to naturally occurring door-to-door fund-raising drives. Thus, when crafting our script, we closely followed generally accepted guidelines in such matters as the provision of information and other theoretically important factors. Such an approach is different from laboratory experiments, wherein the scholar attempts to create a sterile environment that necessitates careful control of individual preferences, others' preferences, group size, and the like.

Table I summarizes our experimental design. The experimental treatments were conducted on four different weekends between October 2 and November 13, 2004. Our design resulted in a sample of 4833 households approached: 1186 in the VCM, 1282 in the VCM with seed money, 963 in the single-prize lottery, and 1402 in the multiple-prize lottery. Of the households approached, 1755 answered the door and spoke to a solicitor, and 522 made a contribution to the Hazards Center.

\section{III.B. Part 2: Recruiting and Training the Solicitors}

As Table I reveals, we employed 44 solicitors: seven in the VCM treatment, twelve in the VCM with seed money treatment, ten in the single-prize lottery treatment, and fifteen in the multiple- 
TABLE I

EXPERIMENTAL DESIGN

\begin{tabular}{|c|c|c|c|c|}
\hline & $\begin{array}{l}\text { Session } 1 \\
\text { Oct } 2-3\end{array}$ & $\begin{array}{l}\text { Session } 2 \\
\text { Oct } 23-24\end{array}$ & $\begin{array}{c}\text { Session } 3 \\
\text { Nov } 6-7\end{array}$ & $\begin{array}{c}\text { Session } 4 \\
\text { Nov } 13\end{array}$ \\
\hline $\begin{array}{l}V C M \\
7 \text { Solicitors }\end{array}$ & $\begin{array}{l}3 \text { Solicitors } \\
607 \text { Approach } \\
208 \text { Home }\end{array}$ & $\begin{array}{l}4 \text { Solicitors } \\
579 \text { Approach } \\
238 \text { Home }\end{array}$ & & \\
\hline $\begin{array}{l}V C M-\text { Seed } \\
\$ 1000 \text { Donation } \\
12 \text { Solicitors }\end{array}$ & $\begin{array}{l}3 \text { Solicitors }^{\mathrm{a}} \\
173 \text { Approach } \\
51 \text { Home }\end{array}$ & $\begin{array}{l}6 \text { Solicitors } \\
662 \text { Approach } \\
236 \text { Home }\end{array}$ & $\begin{array}{l}3 \text { Solicitors } \\
447 \text { Approach } \\
166 \text { Home }\end{array}$ & \\
\hline $\begin{array}{l}\text { Single-prize } \\
\$ 1000 \text { prize } \\
10 \text { Solicitors }\end{array}$ & $\begin{array}{l}2 \text { Solicitors } \\
186 \text { Approach } \\
56 \text { Home }\end{array}$ & $\begin{array}{l}5 \text { Solicitors } \\
515 \text { Approach } \\
194 \text { Home }\end{array}$ & $\begin{array}{l}3 \text { Solicitors } \\
262 \text { Approach } \\
113 \text { Home }\end{array}$ & \\
\hline $\begin{array}{l}\text { Multiple-prize } \\
4 \text { Prizes- } \$ 250 \\
15 \text { Solicitors }\end{array}$ & $\begin{array}{l}3 \text { Solicitors } \\
248 \text { Approach } \\
99 \text { Home }\end{array}$ & $\begin{array}{l}4 \text { Solicitors } \\
440 \text { Approach } \\
148 \text { Home }\end{array}$ & $\begin{array}{l}4 \text { Solicitors } \\
393 \text { Approach } \\
115 \text { Home }\end{array}$ & $\begin{array}{l}4 \text { Solicitors } \\
321 \text { Approach } \\
131 \text { Home }\end{array}$ \\
\hline
\end{tabular}

Each cell represents one unique session in which we gathered data using one of the four treatments: VCM, VCM with Seed Money, Single-Prize Lottery, and Multiple-Prize Lottery. For example, row 1, column 1 , denotes that session 1 of the VCM treatment employed three solicitors who approached a total of 608 houses, of which 208 answered the door. Each solicitor participated in a single session and each household was approached by a single solicitor.

a. In this treatment, the solicitors worked only five hours on Saturday before quitting.

prize lottery treatment. All solicitors participated during a single weekend and elicited contributions within a single treatment. Solicitors were not aware of the alternate treatments, and we took great care to ensure that solicitors in different experimental treatments were isolated from one another to prevent crosscontamination and information exchange across treatments. Each solicitor's experience typically followed four steps: (1) consideration of an invitation to work as a paid volunteer for the research center, (2) an in-person interview, (3) a training session, and (4) participation as a solicitor in the door-to-door campaign.

Undergraduate solicitors were recruited from the student body at ECU via flyers posted around campus, announcements on a university electronic bulletin board, advertisements in the local campus newspaper, and direct appeal to students during undergraduate economics courses. All potential solicitors were told that they would be paid $\$ 10$ per hour during training and employment. Interested solicitors were instructed to contact the Economics Department to schedule an interview.

Initial fifteen-minute interviews were conducted in private offices of the Economics Department faculty. Upon arrival to the 
interview, students completed an application form and a short survey questionnaire. In addition to questions about undergraduate major, GPA, and previous work experience, the job application included questions about height and weight which were used to construct an indicator of body mass index (BMI). The survey questionnaire (see Appendix 2) was composed of twenty categorical-response questions-scaled from (1) strongly disagree to (5) strongly agree-providing information about five potentially important personality traits of the applicant. ${ }^{10}$ Questions were designed to elicit measures of assertiveness, sociability, self-efficacy, performance motivation, and self-confidence. The survey contained two questions each from both a positive and a negative frame for the five traits. Following the literature, we scaled responses from -5 to -1 (negative frame) and 1 to 5 (positive frame); thus, individual measures for the personality traits lie within the set $\{-8,8\}$.

All applicants delivered completed forms to the interviewer prior to the in-person interview. Before the interview began, the interviewer explained the purpose of the nonprofit research center and the nature of the solicitation work that was to be performed. The interview process consisted of a brief review of the applicants' work experience, followed by questions relating to his or her communication skills, confidence in soliciting donations for a nonprofit organization, ability to handle rejection in this context, and motivation for being in college. We video-recorded all in-person interviews, which lasted approximately ten minutes. Upon concluding the interview, every applicant was offered employment as a solicitor.

Once hired, all solicitors attended a one-hour training session. Solicitors were randomly assigned to an experimental treatment and training session. Each training session was conducted by the same researcher and covered a single treatment. ${ }^{11}$ The training sessions provided the solicitor with background/historical information of the Hazards Center and reviewed the organization's mission statement. Solicitors were provided a copy of the informational brochure and the press release announcing the

10. In constructing the personality survey, we followed the International Personality Item Pool (see www.ipip.ori.org).

11. For each round of the experiment, we ran separate training sessions for each treatment on the Friday morning before the solicitors canvassed the neighborhoods. The training sessions were typically held a few days after the initial interview process. 
formation of the Hazards Center. Once solicitors were familiarized with the Hazards Center, the trainer reviewed the data collection procedures. Solicitors were provided with a copy of the data record sheet which included columns to record the race, gender, and approximate age of potential donors, along with their contribution level. The trainer stressed the importance of recording contribution (and noncontribution) data immediately upon conclusion of each household visit.

Next, the trainer reviewed the solicitation script and, in the lottery treatments, explained the lottery rules/procedures. At the conclusion of the training session, the solicitors practiced their script in front of the trainer and the other solicitors. When necessary, the trainer provided immediate feedback to the solicitor on ways in which the pitch could be improved. Next, the solicitors had two further opportunities to practice their script by knocking on two different office doors and soliciting contributions in the Economics Department. Personnel in the Economics Department evaluated the "sales pitch," which was used to provide feedback to the solicitor on his or her performance.

\section{III.C. Part 3: Further Solicitor Information: Personal Attractiveness Rankings}

In the final step, we gathered one last piece of information. In the spirit of the procedures of Biddle and Hamermesh [1998], we derived measures of physical attractiveness for each solicitor. Digital photos of each solicitor were taken during the initial interview to prepare an identification badge. Photographs were then randomly allocated into files that contained the pictures of three other solicitors. The files were printed in color and independently evaluated by 152 different observers. The independent observers were undergraduate students from one of two large introductory-level economics courses at the University of Maryland-College Park. ${ }^{12}$

Each observer evaluated twelve different photographs and was asked to place each photograph on a scale of (1) homely,

12. As noted in Biddle and Hamermesh [1998], the notion that physical attractiveness can systematically affect economic outcomes critically depends on the assumption that there are common standards of beauty in any population. Such common standards have been demonstrated in studies by Zebrowitz, Montepare, and Lee [1993], Biddle and Hamermesh [1998], and Mobius and Rosenblatt [2004]. We, therefore, are comfortable using University of Maryland students to evaluate ECU students' physical attractiveness. 
extremely unattractive, to (10) model beautiful or handsome. This resulted in a total sample of 1824 personal attractiveness rankings. Each rater's scores were normalized to yield a standardized scale across different raters. Normalized ratings $a_{i j}^{N}$ were generated as $a_{i j}^{N}=\left(a_{i j}-\bar{a}_{j}\right) / \sigma_{j}$, where $a_{i j}$ is the personal attractiveness ranking of evaluator $j$ for solicitor $i, \bar{a}_{j}$ is the mean personal attractiveness ranking across all solicitors for evaluator $j$, and $\sigma_{j}$ is the standard deviation in personal attractiveness rankings for evaluator $j$. The normalization procedure results in personal attractiveness rankings that are distributed standard normal. To generate our final personal attractiveness measure, the standardized ratings $a_{i j}^{N}$ for each solicitor $i$ were averaged over the evaluators $j$.

Before proceeding to the results discussion, we should highlight a few important design issues. First, as previously noted, in carrying out our door-to-door campaign, we wished to solicit donors in a way that matched, as closely as possible, the current state of the art in fund-raising. We therefore used the local newspaper to advertise the fund-raising campaign to notify the public that the Hazards Center was a legitimate entity and that ECU representatives might be visiting their households in the near future. Second, solicitors were provided an attractive polo shirt on which the name of the nonprofit organization was professionally embroidered and were instructed to wear khaki pants (or shorts) during their door-todoor solicitations in order to provide a formal, standardized appearance. Third, each solicitor wore an identification badge that included his or her picture, name, and city solicitation permit number. Fourth, solicitors distributed an information brochure after introducing themselves to potential donors. Fifth, we randomly allocated solicitors across neighborhoods and treatment type, and solicitors remained in the same treatment throughout the weekend.

Finally, to summarize, we have gathered a rich set of solicitor and household control variables. Not only do we have measures of several potentially relevant solicitor attributes (age, race, gender, work experience, beauty, BMI, and personality scores), we also have gathered data on the households that our solicitors approached. After the interaction with the household, each solicitor filled out data collection forms that included the estimated age, gender, and race of the potential contributor. 


\section{Experimental Results}

Our first set of hypotheses compares the VCMs with the lotteries. Table II presents summary statistics, which includes information on the success of the various treatments, as well as solicitor and household characteristics. Table II indicates, for example, that our solicitors approached 1186 households in the VCM treatment, and had a chance to speak to 446 of these households, of which 113 chose to contribute to the Hazards Center.

In total, we raised $\$ 452, \$ 526, \$ 688$, and $\$ 752$ in the four treatments. ${ }^{13}$ Consistent with our theory, the lottery treatments raised considerably more money than the VCM treatments. Our theory predicts that this increase might occur on both the intensive and extensive margins: first, the percentage of households contributing in the lotteries exceeds the percentage of households contributing in the VCM treatments. Second, the average contribution in the lottery treatments dominates the average contribution in the VCM treatments. We consider these two possibilities in turn.

As summarized in Table II, in the VCM treatment, 25.3 percent of the households (113 out of 446) made a contribution to the Hazards Center. In the seed money treatment, this proportion was only 14.8 percent (67 out of 453 ). For the single- (multiple-) prize lotteries the respective proportions of contributing households were 45.5 percent ( 165 out of 363 ) and 35.9 percent ( 177 out of 493). In constructing a statistical test for these data, it is important to realize that these proportions are independent across the four treatments, but dependent within treatment; i.e., any given solicitor approaches a number of households. We therefore use a conservative test at the solicitor level by calculating the individual solicitor average success rate, and then rank solicitors via these averages.

13. An astute reader will realize that we lost money in this fund-raising drive given our wage rates and fixed costs (though to be consistent with our experimental design, we did ensure that the Center netted $\$ 1000$ in "seed money"). This outcome is in line with "best practice" fund-raising results and therefore provides evidence that our field experiment was "externally valid." For example, Sargeant, Jay, and Lee [2005] show that most charities lose money on their first fund-raising endeavors (typically about half of what they invest). Indeed, in personal communications, fund-raising experts state that over 90 percent of first efforts lose money. This fact highlights the significance of building a long-term relationship with donors, as charities typically earn positive returns on subsequent campaigns from soliciting households on "warm lists" [Sargeant and Kähler 1999]. 
TABLE II

SummaRy Statistics

\begin{tabular}{|c|c|c|c|c|}
\hline & VCM & $\begin{array}{l}\text { VCM with } \\
\text { Seed Money }\end{array}$ & $\begin{array}{l}\text { Single- } \\
\text { Prize } \\
\text { Lottery } \\
\text { (SPL) }\end{array}$ & $\begin{array}{l}\text { Multiple- } \\
\text { Prize } \\
\text { Lottery } \\
\text { (MPL) }\end{array}$ \\
\hline Total households approached & 1186 & 1282 & 963 & 1402 \\
\hline Total households home & 446 & 453 & 363 & 493 \\
\hline $\begin{array}{l}\text { \# of households that } \\
\text { contributed }\end{array}$ & 113 & 67 & 165 & 177 \\
\hline $\begin{array}{l}\text { Percent of households } \\
\text { contributing }\end{array}$ & $25.3 \%$ & $14.8 \%$ & $45.5 \%$ & $35.9 \%$ \\
\hline Total amount raised & $\$ 452.27$ & $\$ 526.00$ & $\$ 688.04$ & $\$ 752.00$ \\
\hline $\begin{array}{l}\text { Average donation per } \\
\text { household that answered } \\
\text { the door }\end{array}$ & $\begin{array}{l}\$ 1.01 \\
(2.52)\end{array}$ & $\begin{array}{l}\$ 1.16 \\
(4.13)\end{array}$ & $\begin{array}{l}\$ 1.89 \\
(4.39)\end{array}$ & $\begin{array}{l}\$ 1.52 \\
(3.45)\end{array}$ \\
\hline Solicitor characteristics & & & & \\
\hline Total \# of solicitors & 7 & 12 & 10 & 15 \\
\hline Average earnings per hour & $\$ 5.71$ & $\$ 4.35$ & $\$ 7.13$ & $\$ 5.81$ \\
\hline Mean beauty rating & $\begin{array}{c}0.31 \\
(0.69)\end{array}$ & $\begin{array}{l}0.03 \\
(0.64)\end{array}$ & $\begin{array}{c}0.04 \\
(0.68)\end{array}$ & $\begin{array}{l}-0.12 \\
(0.58)\end{array}$ \\
\hline Mean body mass index & $\begin{array}{l}22.91 \\
(4.04)\end{array}$ & $\begin{array}{l}21.60 \\
(2.21)\end{array}$ & $\begin{array}{l}27.11 \\
(6.71)\end{array}$ & $\begin{array}{l}25.51 \\
(5.93)\end{array}$ \\
\hline $\begin{array}{l}\% \text { of male Caucasian } \\
\text { solicitors }\end{array}$ & $28.6 \%$ & $16.7 \%$ & $40 \%$ & $33.3 \%$ \\
\hline $\begin{array}{l}\% \text { of female Caucasian } \\
\text { solicitors }\end{array}$ & $42.8 \%$ & $33.3 \%$ & $30 \%$ & $26.7 \%$ \\
\hline $\begin{array}{l}\% \text { of male non-Caucasian } \\
\text { solicitors }\end{array}$ & $14.3 \%$ & $33.3 \%$ & $10 \%$ & $13.3 \%$ \\
\hline $\begin{array}{l}\% \text { female non-Caucasian } \\
\text { solicitors }\end{array}$ & $14.3 \%$ & $16.7 \%$ & $20 \%$ & $26.7 \%$ \\
\hline Mean sociability & $\begin{array}{c}5.28 \\
(1.98)\end{array}$ & $\begin{array}{c}5.17 \\
(2.48)\end{array}$ & $\begin{array}{c}4.5 \\
(2.22)\end{array}$ & $\begin{array}{c}5.33 \\
(2.50)\end{array}$ \\
\hline Mean assertiveness & $\begin{array}{c}6 \\
(2.16)\end{array}$ & $\begin{array}{l}4.75 \\
(2.22)\end{array}$ & $\begin{array}{c}5.3 \\
(1.7)\end{array}$ & $\begin{array}{c}6.27 \\
(1.22)\end{array}$ \\
\hline Mean self-efficacy & $\begin{array}{c}5.14 \\
(1.86)\end{array}$ & $\begin{array}{c}4.33 \\
(1.97)\end{array}$ & $\begin{array}{c}5 \\
(2.26)\end{array}$ & $\begin{array}{c}4.6 \\
(2.02)\end{array}$ \\
\hline $\begin{array}{l}\text { Mean performance } \\
\text { motivation }\end{array}$ & $\begin{array}{c}5.28 \\
(2.63)\end{array}$ & $\begin{array}{c}4.92 \\
(1.93)\end{array}$ & $\begin{array}{c}5.4 \\
(2.32)\end{array}$ & $\begin{array}{l}6.20 \\
(1.7)\end{array}$ \\
\hline Mean self-confidence & $\begin{array}{c}4.28 \\
(2.43)\end{array}$ & $\begin{array}{c}5.67 \\
(1.87)\end{array}$ & $\begin{array}{c}5.9 \\
(1.79)\end{array}$ & $\begin{array}{c}5.4 \\
(1.88)\end{array}$ \\
\hline Household characteristics & & & & \\
\hline$\%$ of male solicitees & $48.7 \%$ & $51.7 \%$ & $53.2 \%$ & $47.1 \%$ \\
\hline$\%$ of female solicitees & $51.3 \%$ & $48.3 \%$ & $46.8 \%$ & $52.9 \%$ \\
\hline Estimated average age & $\begin{array}{c}42.3 \\
(14.4)\end{array}$ & $\begin{array}{c}38.6 \\
(13.8)\end{array}$ & $\begin{array}{c}43.1 \\
(13.1)\end{array}$ & $\begin{array}{c}44.2 \\
(12.4)\end{array}$ \\
\hline
\end{tabular}

Figures in the table represent summary statistics across the different treatments. 


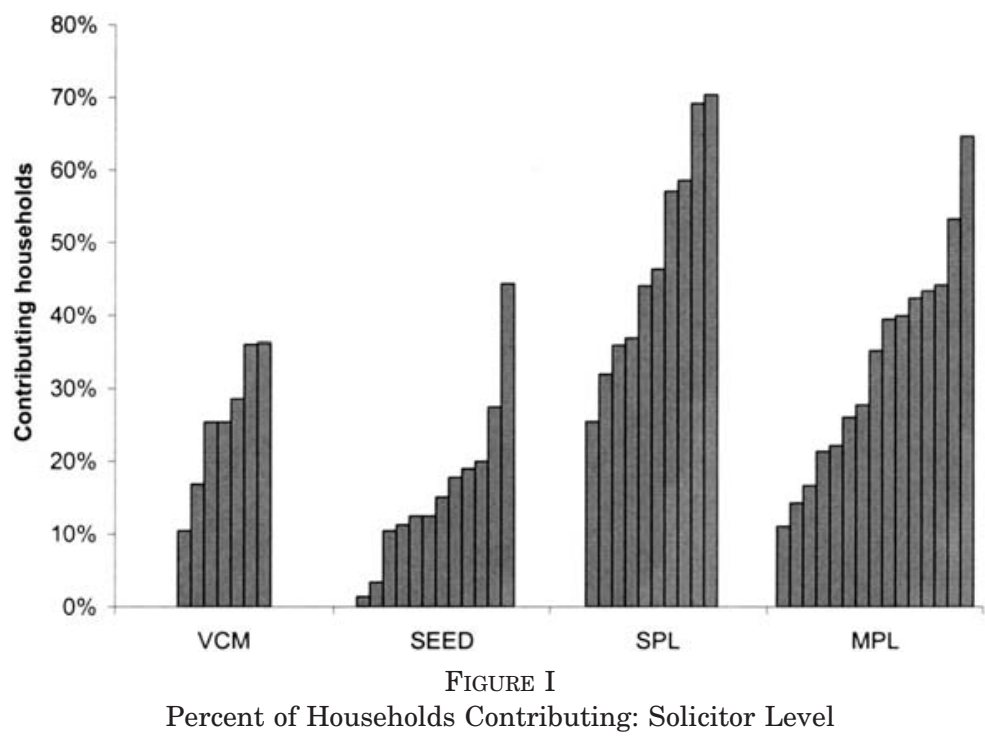

Figure I summarizes success rates by plotting the percentages of households that contributed at the solicitor level; i.e., each observation is a solicitor average. One clear data pattern is that the lotteries induce households to make nonzero donations; for instance, while none of the solicitors in the VCM had a success rate exceeding 40 percent, more than half of the solicitors in the single-prize lottery had a success rate exceeding 40 percent. Using a Mann-Whitney rank sum test on these data, we find that (i) the percentage of households that contributed in the single-prize lottery is significantly greater than the percentage of households that contributed in either the VCM or VCM with seed money treatments at the $p<0.01$ level, and (ii) the percentage of households that contributed in the multiple-prize lottery is significantly greater than the percentage of households that contributed in the VCM with seed money treatment at the $p<0.01$ level. ${ }^{14}$

Considering average contributions, as Table II summarizes, we find that the average donation per contact is greater in our two lottery treatments than in either of the VCM treatments: average

14. Figure I highlights that the observed treatment effect is not merely driven by a few solicitors. Indeed, assuming independence across solicitors, the probability that the top seven solicitors were randomly placed in the SPL (MPL) rather than being placed in the VCM is 0.6 percent (3.4 percent). 


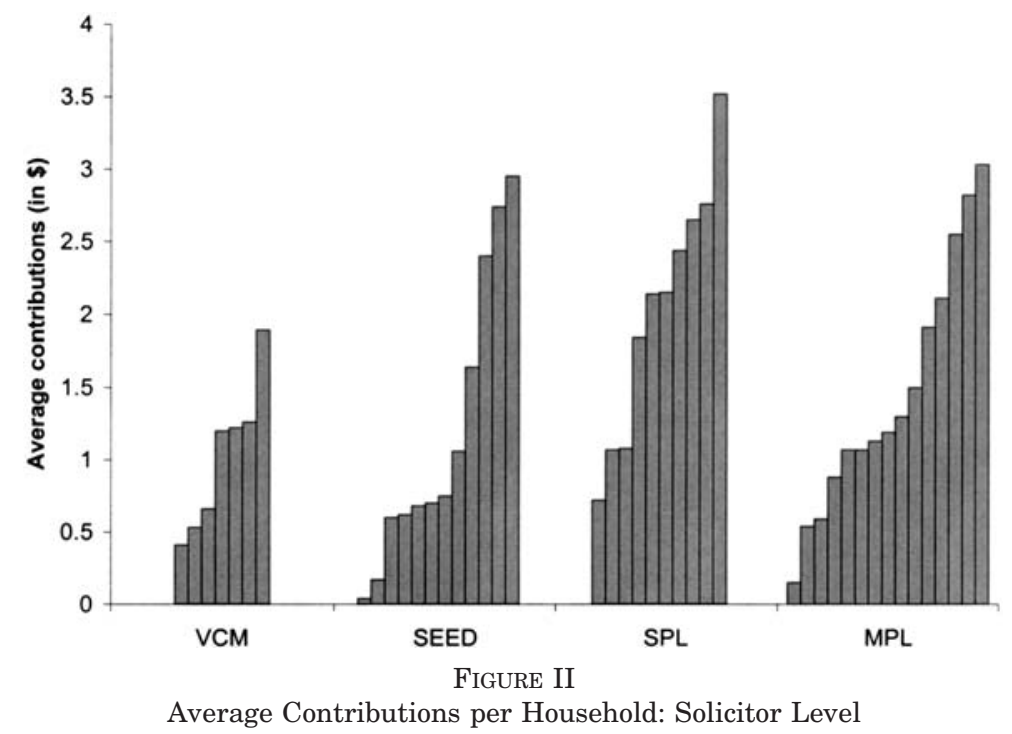

contribution levels per household was $\$ 1.89$ (\$1.52) in the singleprize (multiple-prize) lottery treatment, considerably larger than average contributions under the VCM (VCM with seed money) of $\$ 1.01$ (\$1.16). Figure II presents the average contribution per household at the solicitor level and highlights the effectiveness of the lottery design. Using the average earnings per household for each solicitor as the unit of observation, we find that the $\$ 0.88$ (\$0.73) difference in the single-prize lottery and the VCM (VCM with seed money) treatment is statistically significant at the $p<$ 0.05 level. For the multiple-prize lottery treatment, the $\$ 0.51$ difference from the VCM treatment is statistically significant at the $p<0.10$ level, whereas the difference from the VCM with seed money is not statistically significant.

To complement these unconditional insights, we estimate a series of linear regression models that explicitly control for observable and unobservable differences across solicitors. Specifically, we estimate a linear regression model of the amount contributed for each household that answered the door (including zero contributions) on dummy variables for our experimental treatments and other covariates:

$$
L_{i j}=Z_{i j} \delta+X_{i j} \beta+\varepsilon_{i j},
$$


where $L_{i j}$ is the contribution level of the $j$ th household to the $i$ th solicitor, $\mathbf{Z}$ is a vector of treatment group status indicators, and $\mathbf{X}$ is a vector of other covariates-including observable solicitor and solicitee characteristics as well as weekend-specific effects to control for temporal heterogeneity in giving rates. To account for unobservable heterogeneities at the solicitor level, we cluster the standard errors by solicitor.

Initial empirical estimates presented in Model A of Table III provide insights consistent with the unconditional results: households contributed $\$ 1.00$ ( $\$ 0.79$ ) more in the single (multiple) prize lottery treatment than in the baseline VCM treatment with both of these differences statistically significant at the $p<0.05$ level.

To gain insights into the factors that influence the decision of households to contribute to the Hazards Center, we estimate a linear probability model of the contribution decision of households that answered the door:

$$
C_{i j}=Z_{i j} \delta+X_{i j} \beta+e_{i j}
$$

where $C_{i j}$ equals unity if solicitor $i$ received a contribution for household $j$, and equals zero otherwise. We again cluster the standard errors by solicitor.

Empirical estimates are presented in column 1 (Model A) of Table IV, and indicate that households were more likely to contribute if they were approached by a solicitor who was randomly placed into one of the lottery treatments: households are approximately 20 percent (15 percent) more likely to contribute in the single-prize (multiple-prize) lottery compared with the VCM treatment. And, households were roughly 31 percent ( 26 percent) more likely to contribute in the single-prize (multiple-prize) lottery compared with the VCM with seed treatment. All of these differences are statistically significant at the $p<0.05$ level.

Overall, we interpret the empirical results and data patterns as suggesting two major findings:

Result 1: Gross proceeds in both lottery treatments are larger than proceeds in the VCM and VCM with seed money treatments.

Result 2: The increased revenue stream in lotteries is largely due to increased participation rates, but average contributions are also slightly higher in the lotteries.

These results are consistent with our theory, but it is clearly of interest under which circumstances lotteries would yield a higher 
TABLE III

Total Household Contribution Levels and Solicitor Characteristics

\begin{tabular}{|c|c|c|c|c|c|c|c|}
\hline & $\begin{array}{l}\text { Model } \\
\text { A }\end{array}$ & $\begin{array}{l}\text { Model } \\
\text { B }\end{array}$ & $\begin{array}{l}\text { Model } \\
\text { C }\end{array}$ & $\begin{array}{l}\text { Model } \\
\text { D }\end{array}$ & $\begin{array}{l}\text { Model } \\
\text { E }\end{array}$ & $\begin{array}{l}\text { Model } \\
\text { F }\end{array}$ & $\begin{array}{l}\text { Model } \\
\text { G }\end{array}$ \\
\hline $\begin{array}{l}\text { Dverall constant- } \\
\text { VCM is baseline }\end{array}$ & $\begin{array}{c}1.07^{* *} \\
0.17)\end{array}$ & $\begin{array}{c}1.07^{* *} \\
(0.47)\end{array}$ & $\begin{array}{c}0.95^{* *} \\
(0.42)\end{array}$ & $\begin{array}{c}0.21 \\
(0.53)\end{array}$ & $\begin{array}{c}0.95^{* *} \\
(0.47)\end{array}$ & $\begin{array}{l}1.00 * * \\
(0.41)\end{array}$ & $\begin{array}{l}1.33^{*} \\
(0.74)\end{array}$ \\
\hline $\begin{array}{l}\text { VCM with seed } \\
\text { money }\end{array}$ & $\begin{array}{c}0.29 \\
(0.33)\end{array}$ & $\begin{array}{c}0.56 \\
(0.38)\end{array}$ & $\begin{array}{c}0.58 \\
(0.38)\end{array}$ & $\begin{array}{l}0.64^{*} \\
(0.38)\end{array}$ & $\begin{array}{c}0.56 \\
(0.36)\end{array}$ & $\begin{array}{l}0.61 \\
(0.37)\end{array}$ & $\begin{array}{l}-0.08 \\
(0.45)\end{array}$ \\
\hline Single-prize lottery & $\begin{array}{l}1.00^{* *} \\
(0.36)\end{array}$ & $\begin{array}{c}0.91^{* *} \\
(0.35)\end{array}$ & $\begin{array}{l}0.95^{* *} \\
(0.34)\end{array}$ & $\begin{array}{l}1.03^{* *} \\
(0.35)\end{array}$ & $\begin{array}{l}0.84^{* *} \\
(0.35)\end{array}$ & $\begin{array}{l}0.94^{* *} \\
(0.35)\end{array}$ & $\begin{array}{c}0.15 \\
(0.35)\end{array}$ \\
\hline Multiple-prize lottery & $\begin{array}{l}0.79 * * \\
(0.33)\end{array}$ & $\begin{array}{l}1.06^{* *} \\
(0.29)\end{array}$ & $\begin{array}{l}1.14^{* *} \\
(0.30)\end{array}$ & $\begin{array}{l}1.19 * * \\
(0.32)\end{array}$ & $\begin{array}{l}1.12^{* * *} \\
(0.31)\end{array}$ & $\begin{array}{l}1.11^{* *} \\
(0.31)\end{array}$ & $\begin{array}{l}0.65^{*} \\
(0.33)\end{array}$ \\
\hline $\begin{array}{l}\text { Solicitor beauty } \\
\text { rating }\end{array}$ & & $\begin{array}{c}0.29 \\
(0.18)\end{array}$ & & & & & \\
\hline $\begin{array}{l}\text { Beauty—male } \\
\text { solicitor }\end{array}$ & & & $\begin{array}{l}-0.09 \\
(0.26)\end{array}$ & $\begin{array}{l}-0.03 \\
(0.25)\end{array}$ & $\begin{array}{l}-0.17 \\
(0.24)\end{array}$ & & \\
\hline $\begin{array}{l}\text { Beauty—female } \\
\text { solicitor }\end{array}$ & & & $\begin{array}{l}0.51^{* *} \\
(0.24)\end{array}$ & $\begin{array}{l}0.53 * * \\
(0.24)\end{array}$ & $\begin{array}{l}0.48^{*} \\
(0.26)\end{array}$ & & \\
\hline Overweight solicitor & & 0.57 & 0.57 & 0.51 & 0.69 & 0.57 & $0.81^{*}$ \\
\hline BMI 25-29.9 & & $(0.40)$ & $(0.38)$ & $(0.39)$ & $(0.45)$ & $(0.39)$ & $(0.44)$ \\
\hline Obese solicitor & & -0.19 & -0.21 & -0.22 & -0.32 & -0.22 & $-0.83^{*}$ \\
\hline $\mathrm{BMI} \geq 30$ & & $(0.31)$ & $(0.29)$ & $(0.30)$ & $(0.32)$ & $(0.30)$ & $(0.46)$ \\
\hline $\begin{array}{l}\text { Assertiveness of } \\
\text { solicitor }\end{array}$ & & $\begin{array}{l}-0.12 \\
(0.09)\end{array}$ & $\begin{array}{l}-0.13 \\
(0.09)\end{array}$ & $\begin{array}{l}-0.10 \\
(0.09)\end{array}$ & $\begin{array}{l}-0.13 \\
(0.09)\end{array}$ & $\begin{array}{l}-0.12 \\
(0.09)\end{array}$ & $\begin{array}{l}-0.09 \\
(0.15)\end{array}$ \\
\hline $\begin{array}{l}\text { Self-confidence of } \\
\text { solicitor }\end{array}$ & & $\begin{array}{r}-0.10^{*} \\
(0.06)\end{array}$ & $\begin{array}{r}-0.11^{*} \\
(0.06)\end{array}$ & $\begin{aligned}- & 0.11^{* *}- \\
& (0.05)\end{aligned}$ & $\begin{array}{r}-0.12 * *- \\
(0.05)\end{array}$ & $\begin{array}{r}-0.12^{* *} \\
(0.06)\end{array}$ & $\begin{array}{l}-0.09 \\
(0.06)\end{array}$ \\
\hline Sociability of solicitor & & $\begin{array}{l}-0.07 \\
(0.05)\end{array}$ & $\begin{array}{l}-0.05 \\
(0.05)\end{array}$ & $\begin{array}{l}-0.06 \\
(0.05)\end{array}$ & $\begin{array}{l}-0.04 \\
(0.05)\end{array}$ & $\begin{array}{l}-0.04 \\
(0.05)\end{array}$ & $\begin{array}{l}-0.03 \\
(0.06)\end{array}$ \\
\hline $\begin{array}{l}\text { Performance } \\
\text { motivation }\end{array}$ & & $\begin{array}{c}0.07 \\
(0.06)\end{array}$ & $\begin{array}{l}0.10^{*} \\
(0.05)\end{array}$ & $\begin{array}{l}0.09^{*} \\
(0.05)\end{array}$ & $\begin{array}{l}0.10^{*} \\
(0.05)\end{array}$ & $\begin{array}{l}0.10^{*} \\
(0.06)\end{array}$ & $\begin{array}{l}0.11^{*} \\
(0.06)\end{array}$ \\
\hline $\begin{array}{l}\text { Self-efficacy of } \\
\text { solicitor }\end{array}$ & & $\begin{array}{c}0.20^{* *} \\
(0.09)\end{array}$ & $\begin{array}{l}0.18^{* *} \\
(0.08)\end{array}$ & $\begin{array}{l}0.18 * * \\
(0.08)\end{array}$ & $\begin{array}{l}0.18^{* *} \\
(0.08)\end{array}$ & $\begin{array}{l}0.18 * * \\
(0.08)\end{array}$ & $\begin{array}{c}0.10 \\
(0.11)\end{array}$ \\
\hline Male solicitee & & & & $\begin{array}{l}0.36^{* *} \\
(0.15)\end{array}$ & & & \\
\hline Caucasian solicitee & & & & $\begin{array}{l}0.60^{* *} \\
(0.20)\end{array}$ & & & \\
\hline $\begin{array}{l}\text { Solicitee under the } \\
\text { age of } 30\end{array}$ & & & & $\begin{array}{c}-0.51^{*} \\
(0.28)\end{array}$ & $\begin{array}{c}-0.56^{*}- \\
(0.29)\end{array}$ & $\begin{array}{c}-0.56 * * \\
(0.29)\end{array}$ & $\begin{array}{r}-0.59 * \\
(0.31)\end{array}$ \\
\hline $\begin{array}{l}\text { Solicitee over the age } \\
\text { of } 65\end{array}$ & & & & $\begin{array}{l}-0.21 \\
(0.21)\end{array}$ & $\begin{array}{l}-0.16 \\
(0.20)\end{array}$ & $\begin{array}{l}-0.19 \\
(0.21)\end{array}$ & $\begin{array}{l}-0.20 \\
(0.21)\end{array}$ \\
\hline $\begin{array}{l}\text { Male solicitor and } \\
\text { female solicitee }\end{array}$ & & & & & $\begin{array}{l}-0.12 \\
(0.19)\end{array}$ & & $\begin{array}{l}-0.13 \\
(0.19)\end{array}$ \\
\hline $\begin{array}{l}\text { Female solicitor and } \\
\text { male solicitee }\end{array}$ & & & & & $\begin{array}{l}0.54^{*} \\
(0.31)\end{array}$ & & $\begin{array}{l}0.61^{*} \\
(0.34)\end{array}$ \\
\hline $\begin{array}{l}\text { Female solicitor and } \\
\text { female solicitee }\end{array}$ & & & & & $\begin{array}{l}-0.06 \\
(0.26)\end{array}$ & & $\begin{array}{c}0.03 \\
(0.28)\end{array}$ \\
\hline
\end{tabular}


TABLE III

(CONTINUED)

\begin{tabular}{|c|c|c|c|c|c|c|c|}
\hline & $\begin{array}{l}\text { Model } \\
\text { A }\end{array}$ & $\begin{array}{l}\text { Model } \\
\text { B }\end{array}$ & $\begin{array}{l}\text { Model } \\
\text { C }\end{array}$ & $\begin{array}{l}\text { Model } \\
\text { D }\end{array}$ & $\begin{array}{l}\text { Model } \\
\text { E }\end{array}$ & $\begin{array}{l}\text { Model } \\
\text { F }\end{array}$ & $\begin{array}{c}\text { Model } \\
\text { G }\end{array}$ \\
\hline $\begin{array}{l}\text { Beauty-male } \\
\text { solicitor and male } \\
\text { solicitee }\end{array}$ & & & & & & $\begin{array}{l}-0.42 \\
(0.31)\end{array}$ & \\
\hline $\begin{array}{l}\text { Beauty_male } \\
\text { solicitor and } \\
\text { female solicitee }\end{array}$ & & & & & & $\begin{array}{c}0.16 \\
(0.23)\end{array}$ & \\
\hline $\begin{array}{l}\text { Beauty-female } \\
\text { solicitor and male } \\
\text { solicitee }\end{array}$ & & & & & & $\begin{array}{l}0.79 * * \\
(0.27)\end{array}$ & \\
\hline $\begin{array}{l}\text { Beauty—female } \\
\text { solicitor and } \\
\text { female solicitee }\end{array}$ & & & & & & $\begin{array}{c}0.31 \\
(0.27)\end{array}$ & \\
\hline $\begin{array}{l}\text { Beauty-male } \\
\text { solicitor in VCM }\end{array}$ & & & & & & & $\begin{array}{l}0.003 \\
(0.35)\end{array}$ \\
\hline $\begin{array}{l}\text { Beauty-female } \\
\text { solicitor in VCM }\end{array}$ & & & & & & & $\begin{array}{c}-0.21 \\
(0.41)\end{array}$ \\
\hline $\begin{array}{l}\text { Beauty-male } \\
\text { solicitor in seed }\end{array}$ & & & & & & & $\begin{array}{l}-0.58 \\
(0.58)\end{array}$ \\
\hline $\begin{array}{l}\text { Beauty-female } \\
\text { solicitor in seed }\end{array}$ & & & & & & & $\begin{array}{l}1.07^{*} \\
(0.58)\end{array}$ \\
\hline $\begin{array}{l}\text { Beauty-male } \\
\text { solicitor in SPL }\end{array}$ & & & & & & & $\begin{array}{l}-1.29 \\
(0.85)\end{array}$ \\
\hline $\begin{array}{l}\text { Beauty-female } \\
\text { solicitor in SPL }\end{array}$ & & & & & & & $\begin{array}{l}0.99 * * \\
(0.50)\end{array}$ \\
\hline $\begin{array}{l}\text { Beauty-male } \\
\text { solicitor in MPL }\end{array}$ & & & & & & & $\begin{array}{c}0.07 \\
(1.01)\end{array}$ \\
\hline $\begin{array}{l}\text { Beauty-female } \\
\text { solicitor in MPL }\end{array}$ & & & & & & & $\begin{array}{l}-0.21 \\
(0.54)\end{array}$ \\
\hline Weekend fixed effects & Yes & Yes & Yes & Yes & Yes & Yes & Yes \\
\hline Clustered standard & Yes & Yes & Yes & Yes & Yes & Yes & Yes \\
\hline $\begin{array}{c}\text { Total number of } \\
\text { observations }\end{array}$ & 1754 & 1754 & 1754 & 1754 & 1754 & 1754 & 1754 \\
\hline
\end{tabular}

** Denotes statistical significance at the $p<0.05$ level.

* Denotes statistical significance at the $p<0.10$ level.

Cell entries provide parameter estimates for a linear regression model of contribution levels (including the zeroes) for our experiment. Standard errors are in parentheses and have been clustered around individual solicitor effects. Cell entries can be read as follows: average contribution levels in the SPL treatment (column 1 , row 7) are approximately $\$ 1.00$ greater than those for our baseline VCM treatment. 
TABLE IV

Dichotomous Contribution Decision AND Solicitor ChaRACTERISTiCS

\begin{tabular}{|c|c|c|c|c|c|c|c|}
\hline & $\begin{array}{c}\text { Model } \\
\text { A }\end{array}$ & $\begin{array}{c}\text { Model } \\
\text { B }\end{array}$ & $\begin{array}{l}\text { Model } \\
\text { C }\end{array}$ & $\begin{array}{l}\text { Model } \\
\text { D }\end{array}$ & $\begin{array}{l}\text { Model } \\
\text { E }\end{array}$ & $\begin{array}{l}\text { Model } \\
\text { F }\end{array}$ & $\begin{array}{c}\text { Model } \\
\text { G }\end{array}$ \\
\hline $\begin{array}{l}\text { Overall constant- } \\
\text { VCM is baseline }\end{array}$ & $\begin{array}{l}0.27 * * \\
(0.03)\end{array}$ & $\begin{array}{c}0.28^{* *} \\
(0.08)\end{array}$ & $\begin{array}{c}0.25^{* *} \\
(0.07)\end{array}$ & $\begin{array}{l}0.27 * * \\
(0.08)\end{array}$ & $\begin{array}{l}0.26^{* *} \\
(0.07)\end{array}$ & $\begin{array}{l}0.27 * * \\
(0.07)\end{array}$ & $\begin{array}{r}0.35^{* *} \\
(0.09)\end{array}$ \\
\hline $\begin{array}{l}\text { VCM with seed } \\
\text { money }\end{array}$ & $\begin{array}{r}-0.11^{* *} \\
(0.04)\end{array}$ & $\begin{array}{l}-0.08 \\
(0.06)\end{array}$ & $\begin{array}{l}-0.07 \\
(0.05)\end{array}$ & $\begin{array}{l}-0.06 \\
(0.05)\end{array}$ & $\begin{array}{l}-0.07 \\
(0.05)\end{array}$ & $\begin{array}{l}-0.07 \\
(0.05)\end{array}$ & $\begin{array}{l}-0.10 \\
(0.07)\end{array}$ \\
\hline Single-prize lottery & $\begin{array}{l}0.20^{* *} \\
(0.06)\end{array}$ & $\begin{array}{l}0.19^{* *} \\
(0.06)\end{array}$ & $\begin{array}{l}0.20 * * \\
(0.06)\end{array}$ & $\begin{array}{l}0.21^{* *} \\
(0.06)\end{array}$ & $\begin{array}{l}0.19^{* *} \\
(0.06)\end{array}$ & $\begin{array}{l}0.19^{* *} \\
(0.06)\end{array}$ & $\begin{array}{l}0.17^{* *} * \\
(0.06)\end{array}$ \\
\hline Multiple-prize lottery & $\begin{array}{l}0.15^{* *} \\
(0.05)\end{array}$ & $\begin{array}{c}0.18^{* *} \\
(0.05)\end{array}$ & $\begin{array}{l}0.20 * * \\
(0.05)\end{array}$ & $\begin{array}{l}0.21^{* *} \\
(0.05)\end{array}$ & $\begin{array}{l}0.20 * * \\
(0.05)\end{array}$ & $\begin{array}{l}0.20 * * \\
(0.05)\end{array}$ & $\begin{array}{l}0.19^{* *} \\
(0.05)\end{array}$ \\
\hline $\begin{array}{l}\text { Solicitor beauty } \\
\text { rating }\end{array}$ & & $\begin{array}{l}0.07^{* * *} \\
(0.03)\end{array}$ & & & & & \\
\hline $\begin{array}{l}\text { Beauty—male } \\
\text { solicitor }\end{array}$ & & & $\begin{array}{l}-0.02 \\
(0.04)\end{array}$ & $\begin{array}{l}-0.03 \\
(0.04)\end{array}$ & $\begin{array}{l}-0.04 \\
(0.04)\end{array}$ & & \\
\hline $\begin{array}{l}\text { Beauty—female } \\
\text { solicitor }\end{array}$ & & & $\begin{array}{l}0.12^{* *} \\
(0.04)\end{array}$ & $\begin{array}{l}0.13 * * \\
(0.04)\end{array}$ & $\begin{array}{l}0.12^{* *} \\
(0.04)\end{array}$ & & \\
\hline Overweight solicitor & & 0.04 & 0.04 & 0.04 & 0.05 & 0.04 & 0.06 \\
\hline BMI 25-29.9 & & $(0.05)$ & $(0.05)$ & $(0.05)$ & $(0.05)$ & $(0$. & $(0.05)$ \\
\hline Obese solicitor & & -0.01 & -0.01 & -0.02 & -0.02 & -0.01 & 0.01 \\
\hline $\mathrm{BMI} \geq 30$ & & $(0.06)$ & $(0.06)$ & $(0.06)$ & $(0.06)$ & $(0.06)$ & $(0.08)$ \\
\hline $\begin{array}{l}\text { Assertiveness of } \\
\text { solicitor }\end{array}$ & & $\begin{array}{l}-0.02- \\
(0.01)\end{array}$ & $\begin{array}{r}-0.03 * * \\
(0.01)\end{array}$ & $\begin{array}{c}-0.02^{*}- \\
(0.01)\end{array}$ & $\begin{array}{r}-0.03 * * \\
(0.01)\end{array}$ & $\begin{array}{c}-0.02^{*} \\
(0.01)\end{array}$ & $\begin{array}{l}-0.03 \\
(0.02)\end{array}$ \\
\hline $\begin{array}{l}\text { Self-confidence of } \\
\text { solicitor }\end{array}$ & & $\begin{array}{l}-0.01 \\
(0.01)\end{array}$ & $\begin{array}{l}-0.01 \\
(0.01)\end{array}$ & $\begin{array}{l}-0.01 \\
(0.01)\end{array}$ & $\begin{array}{l}-0.01 \\
(0.01)\end{array}$ & $\begin{array}{l}-0.01 \\
(0.01)\end{array}$ & $\begin{array}{l}-0.01 \\
(0.01)\end{array}$ \\
\hline Sociability of solicitor & & $\begin{array}{r}-0.02^{*} \\
(0.01)\end{array}$ & $\begin{array}{l}-0.01 \\
(0.01)\end{array}$ & $\begin{array}{l}-0.01 \\
(0.01)\end{array}$ & $\begin{array}{l}-0.01 \\
(0.01)\end{array}$ & $\begin{array}{l}-0.01 \\
(0.01)\end{array}$ & $\begin{array}{l}-0.01 \\
(0.01)\end{array}$ \\
\hline $\begin{array}{r}\text { Performance } \\
\text { motivation }\end{array}$ & & $\begin{array}{c}0.01 \\
(0.01)\end{array}$ & $\begin{array}{l}0.02^{*} \\
(0.01)\end{array}$ & $\begin{array}{l}0.02 * \\
(0.01)\end{array}$ & $\begin{array}{l}0.02^{* *} \\
(0.01)\end{array}$ & $\begin{array}{c}0.02^{* *} \\
(0.01)\end{array}$ & $\begin{array}{c}0.01 \\
(0.01)\end{array}$ \\
\hline $\begin{array}{l}\text { Self-efficacy of } \\
\text { solicitor }\end{array}$ & & $\begin{array}{l}0.03^{* * *} \\
(0.01)\end{array}$ & $\begin{array}{l}0.02^{*} \\
(0.01)\end{array}$ & $\begin{array}{l}0.02^{*} \\
(0.01)\end{array}$ & $\begin{array}{l}0.02^{*} \\
(0.01)\end{array}$ & $\begin{array}{l}0.02^{*} \\
(0.01)\end{array}$ & $\begin{array}{c}0.03 \\
(0.02)\end{array}$ \\
\hline Male solicitee & & & & $\begin{array}{c}0.02 \\
(0.02)\end{array}$ & & & \\
\hline Caucasian solicitee & & & & $\begin{array}{l}-0.02 \\
(0.04)\end{array}$ & & & \\
\hline $\begin{array}{l}\text { Solicitee under the } \\
\text { age of } 30\end{array}$ & & & & $\begin{array}{c}-0.11^{* *}- \\
(0.03)\end{array}$ & $\begin{array}{c}-0.11^{* *}- \\
(0.03)\end{array}$ & $\begin{array}{c}-0.11 * *- \\
(0.03)\end{array}$ & $\begin{array}{r}-0.11^{* *} \\
(0.03)\end{array}$ \\
\hline $\begin{array}{l}\text { Solicitee over the age } \\
\text { of } 65\end{array}$ & & & & $\begin{array}{c}-0.08^{* *}- \\
(0.03)\end{array}$ & $\begin{array}{c}-0.08^{* *}- \\
(0.03)\end{array}$ & $\begin{array}{c}-0.08^{* *} \\
(0.03)\end{array}$ & $\begin{array}{l}-0.07 \\
(0.03)\end{array}$ \\
\hline $\begin{array}{l}\text { Male solicitor and } \\
\text { female solicitee }\end{array}$ & & & & & $\begin{array}{l}-0.01 \\
(0.02)\end{array}$ & & $\begin{array}{r}-0.002 \\
(0.02)\end{array}$ \\
\hline $\begin{array}{l}\text { Female solicitor and } \\
\text { male solicitee }\end{array}$ & & & & & $\begin{array}{c}0.04 \\
(0.04)\end{array}$ & & $\begin{array}{c}0.05 \\
(0.04)\end{array}$ \\
\hline $\begin{array}{l}\text { Female solicitor and } \\
\text { female solicitee }\end{array}$ & & & & & $\begin{array}{c}0.01 \\
(0.04)\end{array}$ & & $\begin{array}{c}0.01 \\
(0.04)\end{array}$ \\
\hline
\end{tabular}


TABLE IV

(CONTINUED)

\begin{tabular}{|c|c|c|c|c|c|c|c|}
\hline & $\begin{array}{l}\text { Model } \\
\text { A }\end{array}$ & $\begin{array}{l}\text { Model } \\
\text { B }\end{array}$ & $\begin{array}{l}\text { Model } \\
\text { C }\end{array}$ & $\begin{array}{l}\text { Model } \\
\text { D }\end{array}$ & $\begin{array}{l}\text { Model } \\
\text { E }\end{array}$ & $\begin{array}{l}\text { Model } \\
\text { F }\end{array}$ & $\begin{array}{c}\text { Model } \\
\text { G }\end{array}$ \\
\hline $\begin{array}{l}\text { Beauty-male } \\
\text { solicitor and male } \\
\text { solicitee }\end{array}$ & & & & & & $\begin{array}{l}0.04 \\
(0.05)\end{array}$ & \\
\hline $\begin{array}{l}\text { Beauty_male } \\
\text { solicitor and } \\
\text { female solicitee }\end{array}$ & & & & & & $\begin{array}{l}0.02 \\
(0.04)\end{array}$ & \\
\hline $\begin{array}{l}\text { Beauty_female } \\
\text { solicitor and male } \\
\text { solicitee }\end{array}$ & & & & & & $\begin{array}{l}0.12^{* *} \\
(0.04)\end{array}$ & \\
\hline $\begin{array}{l}\text { Beauty_female } \\
\text { solicitor and } \\
\text { female solicitee }\end{array}$ & & & & & & $\begin{array}{l}0.14^{* *} \\
(0.05)\end{array}$ & \\
\hline $\begin{array}{l}\text { Beauty-male } \\
\text { solicitor in VCM }\end{array}$ & & & & & & & $\begin{array}{l}-0.09 \\
(0.06)\end{array}$ \\
\hline $\begin{array}{l}\text { Beauty-female } \\
\text { solicitor in VCM }\end{array}$ & & & & & & & $\begin{array}{c}0.08 \\
(0.07)\end{array}$ \\
\hline $\begin{array}{l}\text { Beauty-male } \\
\text { solicitor in seed }\end{array}$ & & & & & & & $\begin{array}{c}-0.12 \\
(0.08)\end{array}$ \\
\hline $\begin{array}{l}\text { Beauty-female } \\
\text { solicitor in seed }\end{array}$ & & & & & & & $\begin{array}{c}0.12^{*} \\
(0.07)\end{array}$ \\
\hline $\begin{array}{l}\text { Beauty-male } \\
\text { solicitor in SPL }\end{array}$ & & & & & & & $\begin{array}{c}0.11 \\
(0.10)\end{array}$ \\
\hline $\begin{array}{l}\text { Beauty-female } \\
\text { solicitor in SPL }\end{array}$ & & & & & & & $\begin{array}{l}0.20^{* *} \\
(0.06)\end{array}$ \\
\hline $\begin{array}{l}\text { Beauty-male } \\
\text { solicitor in MPL }\end{array}$ & & & & & & & $\begin{array}{l}-0.01 \\
(0.11)\end{array}$ \\
\hline $\begin{array}{l}\text { Beauty-female } \\
\text { solicitor in MPL }\end{array}$ & & & & & & & $\begin{array}{l}0.12^{*} \\
(0.07)\end{array}$ \\
\hline Weekend fixed effects & Yes & Yes & Yes & Yes & Yes & Yes & Yes \\
\hline $\begin{array}{l}\text { Clustered standard } \\
\text { errors }\end{array}$ & Yes & Yes & Yes & Yes & Yes & Yes & Yes \\
\hline $\begin{array}{c}\text { Total number of } \\
\text { observations }\end{array}$ & 1754 & 1754 & 1754 & 1754 & 1754 & 1754 & 1754 \\
\hline
\end{tabular}

** Denotes statistical significance at the $p<0.05$ level.

* Denotes statistical significance at the $p<0.10$ level.

Cell entries provide parameter estimates for an OLS model estimating the dichotomous decision of whether or not a household made a contribution to the Hazards Center. Standard errors are in parentheses and have been clustered around individual solicitor effects. Cell entries can be read as follows: agents in the single-prize lottery treatment (column 3, row 7) are 17 percent more likely on average to contribute to the Hazards Center than in the VCM. 
provision level of the public good. ${ }^{15}$ Consider the single-prize lottery treatment. In this case, 963 households were approached, and $\$ 688$ was raised, for an average yield of $\$ 0.71$ per household approached. In the VCM treatment, the average yield was roughly $\$ 0.38$. Thus, if we make the assumption that gift rates would have continued in the same pattern if we visited a larger number of homes, a reasonable conjecture given our randomization scheme, we would need to approach roughly 3030 households in each treatment for the single-prize lottery to net more in proceeds than the VCM.

For charities interested in long-run success, Result 2 is quite important, as it provides evidence of a "double-dividend" associated with lotteries: not only is the level of contributions higher, but the participation rate is enhanced. ${ }^{16}$ Fund-raisers understand that securing a "warm list" of donors is an important requirement for the long-term viability of a charity. In this light, it is important to realize that 40 percent to 80 percent more households contribute in the lotteries compared with the VCM treatments. Informal investigation of what this additional 40 to 80 percent pool of active contributors actually means to a charity leads us to believe that each extra contributor amounts to roughly $\$ 65$ per year in donations. ${ }^{17}$

15. For certain parameter values, the theory would predict such a superiority of lotteries even for net revenues. As the simplest example, consider symmetric risk-neutral agents who do not experience any warm-glow from giving. Then, VCM with seed provision would be given by $1=h^{\prime}\left(G^{S}\right)$ while the single prize lottery gives

$$
1-h^{\prime}\left(G^{S P L}\right)=\frac{n-1}{n} \frac{P}{G^{S P L}}>0,
$$

which immediately implies a larger contribution level under the lottery treatment than under the VCM; i.e., $G^{S P L}>G^{S}$.

16. Early work on the provisioning of public goods found solutions once every participant decided to participate in the mechanisms (see, e.g., Groves and Ledyard [1977]), and therefore focused on increasing contributions along the intensive margin. In this literature, the provision problem is framed within the context of a social planner whose objective is to provide a desired aggregate level of a public good. The distinction between increased contributions along the intensive and extensive margins is extraneous from the perspective of such a social planner. In many practical applications, fund-raisers are concerned with both the aggregate level of contributions received and the total number of contributors. The participation problem and mechanisms that induce gains along the extensive margin are thus important considerations for practitioners in the field. Our result has an analog in the success of certain types of government procurement contracts [McAfee and McMillan 1989], the success of some auction institutions [McAfee and McMillan 1987; Englebrecht-Wiggans 1993], and the design of income transfer programs [Saez 2002].

17. This is a back-of-the-envelope calculation using estimates provided by several charities. First, charities suggest that the retention rate is roughly 50 to 


\section{IV.A. People Give to People, Not Causes: The Role of Individual Characteristics}

An interesting anecdote among fund-raisers is that "people give to people, not causes." This anecdote perhaps has its roots in a famous statement made by Diogenes Laertius: "He [Aristotle] used to say that personal beauty was a better introduction than any letter." 18 In our theory, such effects manifest themselves through the $\gamma$ parameter.

Our data set is sufficiently rich to enable us to examine such an assertion by exploring the effects of individual characteristics-i.e., physical attractiveness, obesity, self-confidence, etc.- on observed contribution levels. Some of these characteristics have been shown, in quite different environments, to have an important influence on economic outcomes (see, e.g., Hamermesh and Biddle [1994], Biddle and Hamermesh [1998], and Mobius and Rosenblatt [2004]).

\section{IV.B. Physical Attractiveness and Giving Behavior}

The middle panel of Table II summarizes solicitor characteristics across the four treatments. These figures can be read as follows: in the VCM treatment the average standardized personal attractiveness rating was 0.31 with a standard deviation of 0.69 . There are notable differences in standardized personal attractiveness ratings across our experimental treatments, but these differences are not statistically significant at any meaningful level using either a two-sample $t$-test for differences in means or a nonparametric Mann-Whitney test.

While our use of "beauty" follows a rich literature, measures of individual body mass have also been used in economic analyses (see, e.g., Coller, Harrison, and McInnes [2002]). As discussed previously, we gathered information on solicitor height and weight, which allows us to compute a body mass index for each individual, which is a measure of body fat based on height and weight that applies to both adult men and women. BMI categories are as follows: underweight, $\mathrm{BMI}=<18.5$; normal weight, $\mathrm{BMI}=$

80 percent (i.e., 50 to 80 percent of those who initially donate will contribute during the next round of solicitations). Second, of those 50 to 80 percent who are retained, they give approximately $\$ 100$ per year (though this figure appears too large for our setting). Our next step in this investigation is to explore this anecdotal evidence.

18. This quote is taken from Hamermesh and Biddle [1994]. 
18.5-24.9; overweight, BMI $=25-29.9$; and obese, BMI of 30 or greater. ${ }^{19}$

We estimated augmented variants of Model A in Tables III and IV to include subject-specific measures in $\mathbf{X}$. These empirical estimates are contained in Models B and C of Tables III and IV. In terms of the beauty rating, Model B in Table III provides some evidence that personal attraction matters. A one-unit increase in personal attractiveness generates an approximate $\$ 0.29$ increase in average household contributions. Yet this estimate is not statistically significant at conventional levels.

Exploring this result a level deeper, Model $\mathrm{C}$ allows for the beauty effect to be heterogeneous across gender and finds that the effect of physical attractiveness is driven largely by females. The estimate in Model C in Table III suggests that a one-standard deviation increase in female personal attractiveness is correlated with an extra $\$ 0.51$ donated-or approximately 44.7 percent (53.7 percent) of the estimated treatment effect for the multipleprize (single-prize) lottery. Interestingly, upon delineating the effect of physical attractiveness even further by controlling for both the race and gender of the solicitor, we find that the effect of a one-standard deviation increase in physical attractiveness for White females is approximately 68.3 percent ( 87.3 percent) of the estimated treatment effect for the single-prize (multiple-prize) lottery. ${ }^{20}$ In this spirit, the effect of female solicitor physical attractiveness is nearly equivalent to the treatment effect of moving from our theoretically most attractive approach (lotteries) to our least attractive approach (voluntary contributions).

Models B and C in Table IV report that part of this effect is driven by increased participation: more personally attractive female solicitors induce a larger proportion of households to contribute. This result suggests that the effect of personal attractiveness is similar to that of the lottery incentive-personal attractiveness elicits contributions from agents who would otherwise elect not to contribute. This insight leads to our next result:

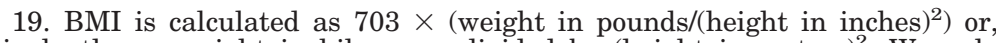
equivalently, as weight in kilograms divided by (height in meters) ${ }^{2}$. We only observe underweight solicitors in our seed money treatment so we have pooled the data on underweight solicitors with those of normal BMI. All empirical results, however, are robust to including an indicator variable for underweight solicitors.

20. We refer the interested reader to Landry, Lange, List, Price, and Rupp [2005] for results from a model that includes the interaction of the race and gender of the solicitor with the average beauty ranking. 
Result 3: Physically attractive female solicitors raise more money than their peers, and this is partly due to increased participation rates among contributors.

This result can be pushed a bit harder by considering the hourly earnings of solicitors. Such estimates provide a rare glimpse at real productivity differences across agents of varying personal attractiveness. The raw data show that a one-standard deviation increase in personal beauty increases hourly returns from approximately $\$ 6$ to more than $\$ 12$, or about 100 percent. We should caveat this result by reminding the reader that this insight is obtained from only a handful of solicitors.

Considering the correlation between BMI and solicitor effectiveness, we find limited evidence of any relationship. For example, while Models B and C in Table III suggest that solicitors labeled obese (BMI $\geq 30$ ) raise lower amounts of money than their peers-such solicitors received average contributions that were approximately $\$ 0.20$ lower than their nonobese peers-it is important to note that these estimates are measured imprecisely. Such imprecision leads us to conclude tentatively that there is little statistical difference in the average contributions received by obese solicitors and their nonobese peers.

\section{IV.C. Self-Efficacy and Performance Motivation: The Influence of Personality}

Economists have recently provided theoretical models relating individual self-confidence (or related personality constructs) and market outcomes (see, e.g., Bearden, Hardesty, and Rose [2001] and Bénabou and Tirole [2002]). The lower portion of the middle panel in Table II presents summary statistics on such measures across our solicitors. Again, there is variation in these measures across our four treatments.

Empirical results in Models B and C in Table III also include personality attributes in $\mathbf{X}$. Empirical results suggest that solicitor self-efficacy, self-confidence, and performance motivation are correlated with the contributions received. For example, a oneunit increase in solicitor self-efficacy (performance motivation) in Model C generates an approximate $\$ 0.18(0.10)$ increase in average contribution levels. Overly self-confident solicitors, however, seemingly "turn off" solicitees and gather less money than their more timid peers. Examining these results in greater detail, we find that much of these effects come from the impacts on average participation rates. For example, Model C in Table IV suggests 
that a one-unit increase in the performance motivation generates an approximate 2 percent increase in average probability of eliciting a contribution. Additional results presented in Table IV suggest that solicitor assertiveness negatively impacts average participation rates. Overall, the set of empirical estimates leads us to our next result:

Result 4: Personality attributes are correlated with solicitor productivity. A primary effect of personality traits is on the probability that the solicitor will elicit a contribution.

This result conforms to intuition and is largely consistent with extant theoretical models.

Models D-G in Tables III and IV extend the above specifications by systematically augmenting $\mathbf{X}$. Model D includes controls for household characteristics-gender, race, and three categories indicating the estimated age of the solicitee; Model E examines the gender interaction of solicitors and solicitees; Model F extends Model E by interacting beauty with gender of solicitor; and Model $\mathrm{G}$ interacts solicitor characteristics with treatment indicators.

These models provide several interesting insights. First, in every model we find that measured treatment effects remain strongly significant, lending further support to Results 1 and 2. Second, use of the interaction terms permits a test of genderspecific treatment effects, which leads to an interesting asymmetry. Model F in Table III, for example, suggests that the beauty results in the other estimated models are entirely driven by households where a male answered the door, as the BeautyFemale Solicitor and Male Solicitee variable is the only interaction that remains significant. ${ }^{21}$ Results for whether the household contributed, however, show that beauty and the decision to give are correlated for both male and female solicitees (see Table IV, Model F). Finally, Model G reveals that the beauty effect occurs in both the VCM and the lottery treatments: in Table III both the VCM with seed money and single prize lottery treatments show a beauty effect, and in Table IV the VCM with seed money and both lottery treatments reveal a beauty effect.

21. In Landry, Lange, List, Price, and Rupp [2005] we further explore this result and find that it is largely driven by the personal attractiveness of White female solicitors. Roughly, we find that a one-standard deviation increase in personal attractiveness increases the expected gift by 50 percent to 135 percent in these cases. This effect is similar in magnitude to the treatment effect of moving from the VCM to the lotteries. 


\section{Assessing Alternative Interpretations of the EXPERIMENTAL FindingS}

The goal of our theoretical framework is to provide a parsimonious model to compare the critical link between lotteries and public good provisioning. The model highlights that lotteries can outperform VCMs even when traditional explanations, such as risk-loving behavior or consumption of gambling, are suppressed. Given that our field experiment provides a glimpse of behavior in the natural environment that our theory intends to explain, alone it cannot discriminate between such alternative explanations. What is necessary to explore the underlying structure at work is complementary evidence.

If the motive for giving in our lotteries is pure love of gambling or risk-loving behavior, then variation in the social value of the public good should have no effect on betting behavior. Further, under either of these alternative motives, variation in the structure of the prize payment scheme should have no effect on giving rates. We present new experimental evidence, evidence from naturally occurring data, and anecdotal evidence that is at odds with these alternative motives and in support of our theory.

For our experimental evidence, ideally we would have preferred to conduct a "pure" lottery field treatment to examine the relationship between the social value of the public good and betting behavior, but North Carolina statute $\S 14-309.15$ states that it is illegal to run a raffle in North Carolina for which the proceeds do not go to a nonprofit. We are, however, able to provide evidence from laboratory experiments to test this critical link.

In Appendix 3 we describe our experimental design and present our data. A more patient description of the experiment and results is provided in Lange, List, and Price [2005]. In our setting, if agents de-link lottery contributions from the provision of the public good, then altering the marginal per capita return (MPCR) to such contributions should not impact contributions. Figure III in Appendix 3 summarizes average contribution levels for agents within each of the three different MPCR levels across both the single- and multiple-prize lottery treatments. As illustrated in the figure, average contribution levels are increasing in the per capita return to the public account. In the single-prize lottery, average contribution levels for agents with an MPCR of 0.10 is approximately 45 percent of the original endowment (100 tokens). As the MPCR increases to 0.90 , the average contribution level increases to approximately 75 percent of the original endow- 
ment. A similar pattern of behavior emerges for the multipleprize lottery. Such a pattern of behavior is inconsistent with a "love of gambling" theory and provides support for our theoretical model.

We have also gathered naturally occurring data in an effort to understand the causes of the data patterns observed in our field experiment. Our approach is to compare annual per capita lottery expenditures across states that earmark lottery proceeds for primary education versus those that allocate lottery proceeds to the state's "general fund." If agents de-link lottery contributions from the provision of the public good, then we would not expect there to be any differences in per capita lottery expenditures.

Using state-level panel data from 1990-2000, we estimated several empirical models that regressed the natural logarithm of annual per capita lottery expenditures on a vector of regressors, including a dichotomous variable for the earmarking of lottery proceeds along with state and year fixed effects. Empirical estimates for these models are included in Appendix 4, and provide insights suggestive of the importance of linking lottery purchases with the provision of a public good: per capita lottery expenditures are greater when proceeds are earmarked for primary education versus the state's general fund, with this difference being statistically significant at the $p<0.05$ level across our various specifications.

Further empirical evidence consistent with our theory can be obtained by recognizing that the jackpot "rollover" characteristic of many naturally occurring lotteries presents a useful natural experiment about lottery motives. For example, Cook and Clotfelter [1993] show that the betting response to the rollover amount is disproportionate compared with the pari-mutuel part. This is consistent with our theory but inconsistent with the proposed alternatives. ${ }^{22}$ Finally, there is considerable anecdotal evidence in support of the linkage as well, as noted by comments from a Pennsylvania official who stated [Douglas 1995, p. 365]: "One of the secrets of the Pennsylvania lottery is having targeted the proceeds. And having the public know where the money goes really seems to help ticket sales." ${ }^{23}$

22. See also the laboratory evidence in Dale [2004].

23. As an aside, consider another piece of anecdotal evidence. Suppose that risk-loving motives were paramount. In this case, if one assumed the analog of decreasing absolute risk aversion, then richer individuals would be the most risk-loving and hence the most likely to play lotteries. This conjecture is not supported in the data. We thank John Morgan for this insight. 


\section{Concluding Remarks}

This study moves toward an understanding of the economics of charity by exploring the demand side of charitable fundraising. We approached nearly 5000 households in an actual door-to-door fund-raiser designed to test our theory while simultaneously raising capital for the Natural Hazards Mitigation Research Center, a new research think tank at East Carolina University. Following our theoretical model, we randomly divided solicitors into four distinct treatments: two that made use of variants of the popular voluntary contribution mechanism, and two that used lotteries.

Empirical results are in line with our theoretical predictions-lottery treatments raised roughly 50 percent more in gross proceeds than our VCM treatments. This result is driven largely by an approximate 100 percent increase in the participation rates for the lotteries, which highlights an attractive feature of lotteries that is rarely discussed: they provide fund-raisers with a tool to generate "warm lists." This result has several analogs in the economics literature. For example, inducing participation among agents who would otherwise not participate is at the crux of the work on the success of certain types of government procurement contracts [McAfee and McMillan 1989]. Whereas these authors are concerned with minimizing costs-they find that granting price preferences to certain bidders can reduce expected contracting costs-the underlying mechanism works in much the same manner that lotteries operate to induce higher revenues. Other parallels to this finding can be found in the mechanism design literature for publicly provided public goods, auction design, and the like.

We also find that a one-standard deviation in physical attractiveness among White female solicitors is roughly equivalent to the increase in contributions when we move from the VCM to the lottery treatments. This result is largely driven by increased participation rates among male households. Such a finding is interesting in light of the fact that there is little evidence on the relative efficacy of institutional and noninstitutional factors. In this sense, it is surprising to find that a change from the most inferior treatment (VCM) to perhaps one of the most attractive (lotteries), in a theoretical sense, yields a treatment effect that is similar to a one-standard deviation change in a solicitors' personal attractiveness. 
Appendix 1: Solicitation SCRIPTS

\section{ECU Center for Natural Hazards Mitigation \\ Research-Script}

(If a minor answers the door, please ask to speak to a parent. Never enter a house.)

$\mathrm{Hi}$, my name is I am an ECU student visiting Pitt County households today on behalf of the newly formed ECU Natural Hazards Mitigation Research Center.

(Hand the blue brochure to the resident).

You may recall hurricanes Dennis and Floyd five years ago led to widespread devastation in Eastern North Carolina, hence the State authorized the new Hazards Center.

This research center will provide support and coordination for research on natural hazard risks, such as hurricanes, tornadoes, and flooding.

The primary goal of the center is to reduce the loss of life and property damages due to severe weather events.

We are collecting contributions today on behalf of the new ECU Hazards Center. The Center is a nonprofit organization.

(Single-Prize Lottery)

To raise funds for the new ECU Hazard Center, we are conducting a charitable raffle:

- The winner receives a $\$ 1,000$ prepaid MasterCard.

- For every dollar you contribute, you will receive 1 raffle ticket.

- The odds of winning this charitable raffle are based on your contribution and total contributions received from other Pitt County households.

- The charitable raffle winner will be drawn at the Center on December 17 at noon. The winner will be notified and the results posted on the Center's web site.

- All proceeds raised by the raffle will fund the Hazards Center, which is a nonprofit organization.

Would you like to make a contribution today?

(If you receive a contribution, please write a receipt that includes their name and contribution amount). 
(solicitors in the VCM (lottery) treatments were told that if the resident asks, contributions are (not) tax deductible).

If you have questions regarding the Center or want additional information, there is a phone number and web site address provided on the back of this blue brochure.

Thank you.

Appendix 2: Personality Questionnaire

Assertiveness

1. I take control of things (Positive Frame)

2. I express myself easily (Positive Frame)

3. I am not highly motivated to succeed (Negative Frame)

4. I cannot come up with new ideas (Negative Frame)

Sociability

1. I talk to a lot of different people at parties (Positive Frame)

2. I am skilled in handling social situations (Positive Frame)

3. I have difficulty expressing my feelings (Negative Frame)

4. I often feel uncomfortable around other people (Negative Frame)

Self-Efficacy

1. I formulate ideas clearly (Positive Frame)

2. I am able to think quickly (Positive Frame)

3. I undertake few things on my own (Negative Frame)

4. I never challenge things (Negative Frame)

Performance Motivation

1. I set high standards for myself and others (Positive Frame)

2. I do more than what is expected of me (Positive Frame)

3. I do just enough work to get by (Negative Frame)

4. I think that in some situations it is important that I not succeed (Negative Frame)

Self-Confidence

1. I just know that I will be a success (Positive Frame)

2. I have a lot of personal ability (Positive Frame)

3. I often think that there is nothing I can do well (Negative Frame)

4. I question my ability to do my work properly (Negative Frame) 


\section{Appendix 3: LABORATORY EXPERIMENTS to Test Alternative Theories}

To examine the impact of MPCR on contribution level in the single fixed-prize lottery (SPL) and a multiple-prize lottery (MPL) counterpart of the fixed-prize lottery, we ran a series of laboratory experiments that followed the basic design of Morgan and Sefton [2000]. The data reported come from four different treatments (a single treatment each for the symmetric multiple-prize and single-prize lotteries and a single treatment each for the asymmetric counterparts of these lotteries) and are reported more fully in Lange, List, and Price [2005]. All treatments were conducted at the University of Maryland-College Park and are comprised of multiple sessions held on separate days with different subjects.

At the beginning of the session, each subject was seated at linked computer terminals that were used to transmit all decision and payoff information. The sessions each consisted of twelve rounds, the first two being practice. The subjects were instructed that the practice rounds would not affect earnings. Once the individuals were seated and logged into the terminals, a set of instructions and a record sheet were handed out. The subjects were asked to follow along as the instructions were read aloud. After the instructions were read and the subjects' questions were answered, the first practice round began.

At the beginning of each round subjects were randomly assigned to groups of four. The subjects were not aware of whom they were grouped with, but they did know that the groups changed every round. Each round the subjects were endowed with 100 tokens. Their task was simple: decide how many tokens to place in the group account and how many to keep in their private account. The decision was entered in the computer and also recorded on the record sheet. When all subjects had made their choice, the computer would inform them of the total number of tokens placed in their group account, the number of points from the group account and the private account, as well as the number of bonus points earned. The payoff for the round was determined by summing the points from the group account, points from the private account, and any bonus points received. Once each of the subjects had recorded this information, the next round would begin.

The points for each round were determined as follows. For all sessions, subjects received one point for each token placed in their private account. In the sessions with symmetric valuations for 
the public good, they were awarded 0.3 points for each token placed in the group account by themselves and other members of their group. In the sessions with asymmetric valuations for the public good, subjects were awarded with either 0.9 or 0.1 points for each token placed in the group account by themselves and the other members of their group. ${ }^{24}$ Additionally, each session had a different method for earning bonus points.

In the single fixed-prize lottery sessions, group members competed for a lottery prize of 80 points. Each subject's chance of the winning the prize was based on his or her contribution to the group account relative to the aggregate number of tokens placed in the group account by all group members. For the n-prize lottery sessions, group members competed for three lottery prizes of values 50,20 , and 10 points, respectively, where each agent could not win more than one prize. As in the single fixed-prize lottery sessions, a subject's chance of winning first prize was based on his or her share of group contributions. The three prizes were awarded in order of value and without replacement.

At the end of the session, one of the nonpractice rounds was chosen at random as the round that would determine earnings. Subjects were paid $\$ 1.00$ for every 15 points earned. In a second experiment, we obtained measures of individual risk aversion coefficients for every participant.

Figure III summarizes average contribution levels for agents with each of the three different MPCR levels across both the single(denoted SPL) and multiple-prize lottery (MPL) treatments. ${ }^{25}$

\section{Appendix 4: State Lottery Expenditures AND the Link with Public Good Provision}

This appendix uses naturally occurring data to provide insights on the importance of linking lottery purchases with the provision of a public good. To test whether agents consider the link between lottery purchases and public good provision, we regress annual per capita lottery expenditures on a dummy variable for states that earmark lottery proceeds for primary educa-

24. In the asymmetric sessions, there was one agent in each group of four who had a valuation for the public account of 0.9 and three agents who had valuations of 0.1 for tokens placed in the group account. Individual valuations were held constant through the sessions, and each group of four had exactly one member with the high valuation and three members with the low valuation.

25 . In terms of testing the alternative hypotheses, these results are in line with Morgan and Sefton [2000]. 


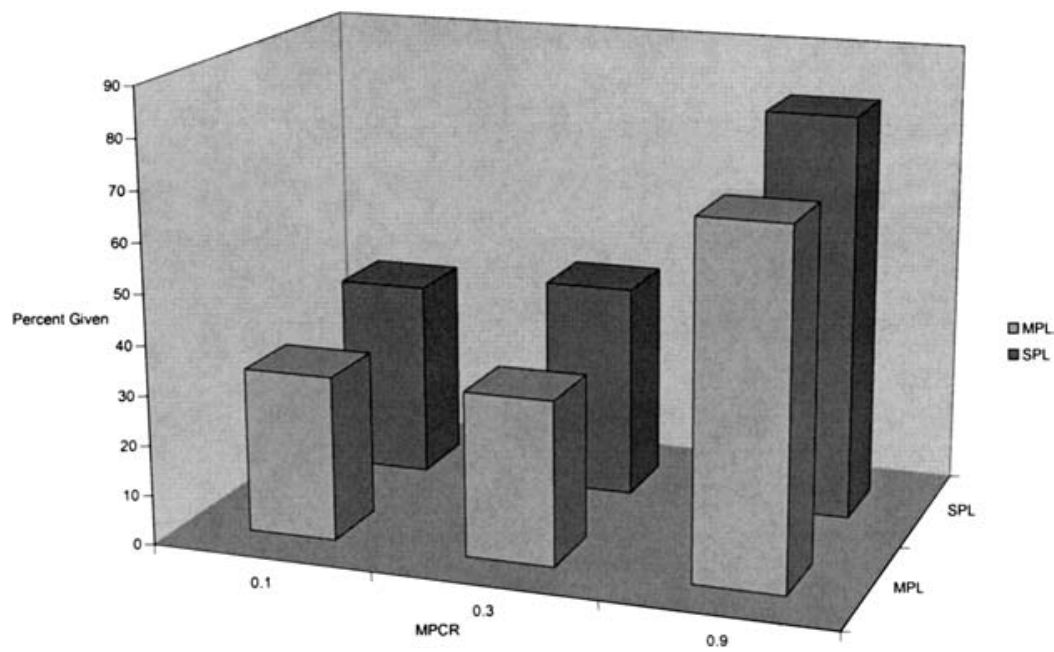

FiguRe III

Lottery Contributions as Function of MPCR in Laboratory Markets

This figure reports the percentage of tokens contributed to the public account across a series of laboratory experiments. For each session, the total value of the prize provided to the lottery winners was held constant at 80 bonus points (approximately \$5.33). The data provide information on 144 unique subjects-36 subjects in each treatment with an MPCR $=0.30,27$ subjects in each treatment with an MPCR $=0.10$, and 9 subjects in each treatment with an MPCR $=0.90$.

tion in the given year along with state and year fixed effects. Specifically, we estimate

$$
\operatorname{Exp}_{i t}=Z_{i t} \beta+\alpha_{i}+\eta_{t}+\varepsilon_{i t},
$$

where $\operatorname{Exp}_{i t}$ is the natural log of annual per capita lottery expenditures for state $i$ in year $t, Z_{i t}$ is an indicator variable that equals one if state $i$ earmarked lottery proceeds in year $t, \alpha_{i}$ are state fixed effects, and $\eta_{t}$ are year fixed effects. ${ }^{26}$

Table $\mathrm{V}$ presents results from two panel data regression

26. During this time period, we observe per capita lottery expenditures in twelve states that exclusively allocated proceeds to the state's general fund, nine states that earmarked funds exclusively for primary education and six states that switched the allocation of lottery proceeds between the state's general fund and primary education. Of the six states that switched how lottery proceeds were allocated, Montana went from designating funds for primary education to the state's general fund. The remaining five states changed the designation of lottery proceeds from the state's general fund to primary education. All data on lottery revenue come from the U. S. Bureau of the Census, State Government Finances, series GF, No. 3 annual. Population data are taken from the 2004-2005 Statistical Abstract of the United States. 
TABLE V

Fixed Effects Regression Estimates: Per Capita Lotto Expenditures

\begin{tabular}{lcc}
\hline \hline & Model 1 & Model 2 \\
& Log (Per_Cap_Expenditure) & Log (Per_Cap_Expenditure) \\
\hline Earmark indicator & $0.41^{* *}$ & $0.24^{* *}$ \\
& $(0.10)$ & $(0.08)$ \\
State fixed effects & Yes & Yes \\
Year fixed effects & No & Yes \\
No. of Observations & 288 & 288 \\
No. of States & 27 & 27 \\
\hline \hline
\end{tabular}

models in this spirit. The results provide a comparison of annual per capita lottery expenditures for the period 1990-2000 in states that earmark lottery proceeds for primary education versus those that allocate lottery proceeds to the state's general fund. In both cases, and several other variants of the model, the results are consistent with our underlying framework.

EAST CAROLINA UNIVERSITY

UNIVERSITY OF MARYLAND

UNIVERSITY OF CHICAGO AND NBER

UNIVERSITY OF NEVADA-RENO

EAST CAROLINA University

\section{REFERENCES}

Andreoni, James, "Giving with Impure Altruism: Applications to Charity and Ricardian Equivalence," Journal of Political Economy, XCVII (1989), 1147-1458.

_ "Impure Altruism, and Donations to Public Goods: A Theory of Warm-Glow Giving," Economic Journal, C (1990), 464-477.

— , "Toward a Theory of Charitable Fund-raising," Journal of Political Economy, CVI (1998), 1186-1213.

Andreoni, James, and Ragan Petrie, "Public Goods Experiments without Confidentiality: A Glimpse into Fund-raising," Journal of Public Economics, LXXXVIII (2004a), 1605-1623.

Andreoni, James, and Ragan Petrie, "Beauty, Gender, and Stereotypes: Evidence from Laboratory Experiments," working paper, University of Wisconsin, 2004b.

Bearden, William, David Hardesty, and Randall Rose, "Consumer Self-Confidence: Refinements in Conceptualization and Measurement," Journal of Consumer Research, XXVIII (2001), 121-134.

Bénabou, Roland, and Jean Tirole, "Self-Confidence and Personal Motivation," Quarterly Journal of Economics, CXVII (2002), 871-915.

Bertrand, Marianne, Dean Karlan, Sendhil Mullainathan, Eldar Shafir, and Jonathan Zinman, "What's Psychology Worth? A Field Experiment in the Consumer Credit Market," working paper, Princeton University, 2005.

Biddle, Jeff, and Daniel Hamermesh, "Beauty, Productivity, and Discrimination: Lawyers' Looks and Lucre," Journal of Labor Economics, XVI (1998), 172-201. 
Coller, Maribeth, Glenn Harrison, and Melayne McInnes, "Evaluating the Tobacco Settlement Damage Awards: Too Much or Not Enough," American Journal of Public Health, XCII (2002), 982-989.

Cook, Philip J., and Charles T. Clotfelter, "The Peculiar Scale Economics of Lotto," American Economic Review, LXXXIII (1993), 634-643.

Dale, Donald J., "Charitable Lottery Structure and Fund Raising: Theory and Evidence," Experimental Economics, VII (2004), 217-234.

Douglas, A., British Charitable Gambling 1956-1994, (London, UK: Athlone Press, 1995).

Dufwenberg, Martin, and Astri Muren, "Discrimination by Gender and Social Distance," working paper, Stockholm University, 2002.

Englebrecht-Wiggans, Richard, "Optimal Auctions Revisited," Games and Economic Behavior, V (1993), 227-239.

Fraser, Cynthia, Robert Hite, and Paul Sauer, "Increasing Contributions in Solicitation Campaigns: The Use of Large and Small Anchorpoints," Journal of Consumer Research, XV (1988), 284-287.

Glaeser, Edward L., David I. Laibson, José A. Scheinkman, and Christine L. Soutter, "Measuring Trust," Quarterly Journal of Economics, CXV (2000), 811-846.

Groves, Theodore, and John Ledyard, "Optimal Allocation of Public Goods: A Solution to the 'Free-Rider' Problem," Econometrica, XLV (1977), 783-809.

Hamermesh, Daniel, and Jeff Biddle, "Beauty and the Labor Market," American Economic Review, LXXXIV (1994), 1174-1194.

Harrison, Glenn W., and John A. List, "Field Experiments," Journal of Economic Literature, XXXXII (2004), 1009-1055.

Landry, Craig, Andreas Lange, John A. List, Michael K. Price, and Nicholas G. Rupp, "Toward an Understanding of the Economics of Charity: Evidence from a Field Experiment," NBER Working Paper No. 11611, 2005.

Lange, Andreas, John A. List, and Michael K. Price, "Using Lotteries to Finance Public Goods: Theory and Experimental Evidence," working paper, University of Maryland, 2005.

List, John A., and David Lucking-Reiley, "Effects of Seed Money and Refunds on Charitable Giving: Experimental Evidence from a University Capital Campaign," Journal of Political Economy, CX (2002), 215-233.

McAfee, R. Preston, and John McMillan, "Auctions with Entry," Economics Letters, XXIII (1987), 343-347.

McAfee, R. Preston, and John McMillan, "Government Procurement and International Trade," Journal of International Economics, XXVI (1989), 291-308.

Mobius, Markus, and Tonya Rosenblatt, "Why Beauty Matters," Working Paper, Harvard University, 2004.

Morgan, John, "Financing Public Goods by Means of Lotteries," Review of Economic Studies, LXVII (2000), 761-784.

Morgan, John, and Martin Sefton, "Funding Public Goods with Lotteries: Experimental Evidence," Review of Economic Studies, LXVII (2000), 785-810.

Rodgers, William M., and Charles Stuart, "The Efficiency of a Lottery as a Source of Public Revenue," Public Finance Quarterly, XXIII (1995), 242-254.

Saez, Emmanuel, "Optimal Income Transfer Programs: Intensive versus Extensive Labor Supply Response," Quarterly Journal of Economics, CXVII (2002), 1039-1073.

Sargeant, Adrian, E. Jay, and S. Lee, "Benchmarking Charity Performance: Returns from Direct Marketing in Fundraising," Journal of Nonprofit and Public Sector Marketing (2005), forthcoming.

Sargeant, Adrian, and Jürgen Kähler, "Returns on Fundraising Expenditures in the Voluntary Sector," Nonprofit Management and Leadership, X (1999), 5-19.

Vesterlund, Lise, "The Informational Value of Sequential Fund-raising," Journal of Public Economics, LXXXVII (2003), 627-657.

Zebrowitz, Leslie, Joann Montepare, and Hoon Koo Lee, "They Don't All Look Alike: Individuated Impression of Other Racial Groups," Journal of Personality and Social Psychology, LXV (1993), 85-101. 